\title{
A LEX GÓTICA E O LIBER IUDICUM NO REINO DE LEÓN
}

\author{
POR \\ CLAUDIO RODIÑO CARAMÉS
}

\section{A LEX GÓTICA E O LIBER IUDICUM}

«En términos xerais, a lei [visigoda] é unha boa lei. En verdade, comparada coa dos outros reinos bárbaros, é unha lei excelente...»' ${ }^{1}$. É doado deixarse encandilar pola obra lexislativa dos visigodos: un código legal amplo, completo, ben artellado e ben escrito, que pode ser usado como chave para penetrar e comprender a sociedade visigoda, tal e como fai quen así a descrebe na cita que isto encabeza. Non vai ser ese, sen embargo, nen o obxectivo nen o método do noso traballo, pero non se pode deixar de sentir certa afinidade con esta mostra de simpatía cara á obra central do pensamento e da práctica xurídica visigótica: o Liber Iudiciorum. ${ }^{2} \mathrm{~A}$ razón desta afinidade está en que a Lex e o Liber constitúen

\footnotetext{
' P. D. KING, Derecho y sociedad en el reino visigodo, Madrid 1981, p. 40.

${ }^{2}$ Este título só encabeza un dos máis de trinta códices que se conservan; sen embargo, non se lle pode negar certa preeminencia en tanto que é o manuscrito da Lex máis antigo dos que se conservan (de inicios do VIII, ou mesmo de fins do VII segundo DÍAZ y DÍAZ), así como o único que se pode considerar verdadeira testemuña da forma recesvindiana. Trátase do R1 de ZEUMER, o 1 de DÍAZ y DÍAZ e o (V)aticano de GARCÍA LÓPEZ, e que pertence á zona catalana. O resto dos manuscritos levan por título Liber Iudicum ou Forum Iudicum (donde procede o título da versión romanceada, o Fuero Juzgo). En canto á identificación de cada códice, as anteriores numeracións corresponden ás empregadas polos autores respectivos en: Leges Visigothorum, ed. K.
}

"CUADERNOS DE ESTUDIOS GALLEGOS", Tomo XLIV, Fascículo 109, Santiago 1997. 
tamén o eixo e a referencia desta pescuda, pero son diferentes método e obxectivo porque imos avanzar no tempo e cambiar de reino: o que nos interesa non é cómo unha sociedade crea e modela o seu propio corpus xurídico senon cómo aquela que se considera a súa sucesora (a do reino de León $^{3}$ ) recebe, coñece e usa unha herdanza deste tipo. Por iso, non compre tanto facer unha análise do contido das disposicións legais godas que, se entende, están a reflexar unha organización social concreta (a hispanogoda), como facer, pola contra, unha búsqueda daquelas actitudes e actuacións que se xeneran diante desa herdanza, e que caracterizan esta pervivencia.

Así pois, e malia que xa fóra do reino visigodo, o Liber será o principal protagonista deste traballo. Convén, polo ranto, e aínda que máis non sexa que por facernos unha idea da lex na súa materialidade, comenzar por facer unha pequena descripción da obra. Por fortuna, non temos necesidade de entrar na difícil problemática das recensións; como o noso interese é posvisigodo, non imos tirar ningunha conclusión da identificación exacta das diferentes fases ou edicións deste código: en principio, aceptando ou non a existencia dun labor previo de Chindasvinto, a primeira edición sería a do seu fillo Recesvinto en 654, recollendo unha grande cantidade de antiquae, que arrincarían do $\mathrm{s}$. $\mathrm{V}$ e xa introducidas no Codex revisus de Leovigildo, asi como leis promulgadas de Recaredo en adiante. En 681 a revisión de Ervigio, constitúe a segunda edición deste corpo legal, sobre o que aínda incidiría unha terceira fase, a da laboura lexislativa de Egica e de Witiza. Pero a rigurosa crítica interna, necesaria para fixar as diferentes aportacións lexislativas dos monarcas godos, non ten demasiada utilidade se o que se quere estudiar é a historia do Liber nos séculos que siguen á chegada árabe. Por outra banda as características dunha obra de tradición aberta, como o é esta, na que as pezas, as leis, se poden ir engadindo en distintos momentos, os resultados distan moito de ofrecernos códices que representen, de forma pura, unha ou outra edición real, mal que lle pese a

ZEUMER, M.G.H. Leg. sectio I, Hannover 1902; M. C. DÍAZ Y DÍAZ, "La Lex Visigothorum y sus manuscritos. Un ensayo de reinterpretación", en A.H.D.E. 46 (1976), pp. 163-224; e Y. GARCÍA LÓPEZ, Estudios críticos y literarios de la Lex Wisigothorum, Santiago 1990

${ }^{3}$ Reino de León nun sentido un tanto amplo, xa que tamén se inclúen documentos da última época astur, antes do cambio da corte a León.

"CUADERNOS DE ESTUDIOS GALLEGOS", Tomo XLIV, Fascículo 109, Santiago 1997. 
Zeumer. É por isto que, cando un xuíz do século X ou XI estea a consultar un manuscrito do Liber, non vai ser consciente de estar manexando unha ou outra recensión, ou mellor, unha mistura de todas elas, aínda que o seu uso si sirva despois para tentar seguir, como fai Yolanda García, a tradición da obra. ${ }^{4}$

Estamos diante dun código amplo, que tenta recoller, de forma organizada, tódolos aspectos lexislables e normativizables dunha sociedade; en total, dependendo dos modelos que estea a copiar e a «recensión-base» que poida estar a seguir, un códice completo do Liber incorpora entre 567 e 581 leis. Estas aparecen artelladas en doce libros. Dentro de cada libro, as leis ou sententiae organízanse nun número variado de títulos (cinco ou seis é o máis normal), por contidos, o que permite unha máis doada localización, como se observa nos documentos que citan o Liber por libro, título e sentencia.

En canto á forma, e sen que aquí se queira entrar na rigurosidade das descripcións codicolóxicas, pódese falar de certos rasgos comúns, ou alomenos frecuentes nas copias que conservamos, que se cadra están a remitirnos a un modelo oficial promovido dende Toledo: iníciase o Liber cunha capitulatio no verso do primeiro folio (o recto deixábase en blanco, como garda), na que se recollían os títulos dos libros dentro dunhas rodiñas decoradas con cor e debuxos xeométricos, mentres que ó lado e cara abaixo se escribían os epígrafes dos tituli; de todos xeitos, Díaz y Díaz e Yolanda García coinciden en afirmar que esta presentación debeu ser unha innovación posterior á primeira edición, a de Recesvinto. O texto dispúñase nunha única columna (a non ser que no mesmo códice se inclúan outras

\footnotetext{
${ }^{4}$ De todos xeitos, e aínda que se xustifique deste xeito non tocar aquí o que sería, en sentido estricto, a historia do dereito visigodo, si é conveniente facer referencia, polo menos, ó artigo de L. A. GARCÍA GALLO, «Consideración crítica de los estudios sobre la legislación y costumbre visigodas», en A.H.D.E. 44 (1974), pp. 343-464, ou ó de C. PETIT, «De negotiis causarum», en A.H.D.E. 55 (1985), pp. 155-242 e A.H.D.E. 56 (1986), pp. 5-155, sobre o libro II, que é o que trata as diversas fases do procedemento, complementándose cos títulos primeiros dos libros VI (6,1 De accusationibus criminum) e VII $(7,1$ De iudicibus furti). Se algún libro, dos doce que forman o Liber, amosa para nos un maior interese é sin dúbida este, o II, en canto a que son as normas do proceso visigodo as que, artellando os xuizos no reino de León, conforman a actividade durante a cal se vai botar man do Liber: a xudicial. Unhas formas de facer visigóticas, as do proceso, encadran o emprego material do Liber.
}

"CUADERNOS DE ESTUDIOS GALLEGOS", Tomo XLIV, Fascículo 109, Santiago 1997. 
pezas e, por influencia, se empreguen dúas columnas), cunhas 26/30 liñas por páxina e unhas 30/35 letras por liña, «o que xa delimitaba practicamente a medida do manuscrito que resultaba sempre manexable.» ${ }^{5}$ Cada libro encabézase co seu número e nome dentro doutra rodiña, tamén ornamentada de diversas formas, e cada título, en vermello ou verde, ía seguido dun pequeno índice cos números e encabezamentos das leis, para pasar xa definitivamente as leis do devandito título, precedida cada unha delas polo seu número e intitulatio. As dimensións totais xiraban, se nos fixamos por exemplo nos manuscritos cos que Yolanda García traballa para o reino de León, entorno a unha media de 300 × $200 \mathrm{~mm}$, isto é, unha especie de $\mathrm{A} 4$, o que sin dúbida resalta esa idea de manexabilidade coa que se adoita caracterizar esta obra. ${ }^{6}$

Pechando xa este pequeno apunte previo sobre o Liber, quizais poida ser ilustrativo, á hora de avaliar o peso específico de esta obra, facer unha mínima alusión ós exemplares concretos que hoxe se conservan: de algo mais de trinta manuscritos, un grande maioría pertencen ó que Yolanda García chama rama oriental (narbonesa-catalana-riojana), mentres que apenas oito códices e un pequeno fragmento ${ }^{7}$ se encadran dentro da rama occidental (leonesa-castellana); un simple vistazo ó mapa codicolóxico co que Díaz y Díaz remata o seu artigo ponnos diante desa maior riqueza da zona catalana e da riojana. ${ }^{8}$

${ }^{5}$ M. C. DÍAZ y DÍAZ, op. cit. p. 207. Nesta manexabilidade insiste tamén R. COLLINS en "Literacy and the laity in early mediaeval Spain", en The uses of literacy in Early Medieval Europe, ed. R. McKITTERICK, Cambridge 1990, p. 130.

${ }^{6}$ Para ese modelo quizais oficial, resumín as reflexións que DÍAZ y DÍAZ fai no artigo citado, pp. 202-209, porque creo que nos pode familiarizar co protagonista deste traballo; xa o mesmo autor fai referencia ás reservas que se poidan pór a este modelo, atendendo a se a producción do códice estaba destinada á venda (e polo tanto regulada por V,4,22, onde se fixa o precio do exemplar e, probablemente, tamén se faga referencia ó «aspecto exterior» oficial) ou ben só para uso privado e, xa que logo, susceptible de tomar outra forma. Para as referencias ós códices concretos que conservamos, limitándonos aquí ós do ámbito do reino de León, a principal obra é, dende logo, a tese xa citada de Y. GARCÍA.

${ }^{7}$ Estes códices leoneses teñen unha datación que abrangue dende finais do $\mathrm{s}$. X ou principios do XI, no caso do (T)oledano según a denominación de Y. GARCÍA, ata o s. XIV no que se confecciona o (U); e en canto á súa orixe xeográfica, Toledo, San Zoilo de Carrión ou Palencia son puntos nos que se poideron ter elaborado alguns destes exemplares.

${ }^{8} \mathrm{O}$ devandito mapa en DÍAZ y DÍAZ, op. cit. p. 224. Para este autor, tal abundancia de copias dos séculos VIII-IX na zona de Gerona faille pensar «se non habería un taller de escritura nesta cidade adicado á producción en serie de exemplares, en boa parte con

"CUADERNOS DE ESTUDIOS GALLEGOS", Tomo XLIV, Fascículo 109, Santiago 1997. 
Este relativo desequilibrio lévanos a facer dúas consideracións: en primeiro lugar, que pode ser arriscado facer unha rápida relación de proporcionalidade entre o número de exemplares conservados e o maior ou menor uso da lex nun determinado ámbito xeográfico; e, en segundo lugar, que existen outro tipo de testimonios do manexo do Liber que poden ser tan fiables como a propia conservación dun códice, e que nos poden completar o panórama. Portugal pódenos ilustrar isto: os documentos fornécennos de numerosos casos concretos de uso do Liber, ben en procesos ou ben en doacións, e sen embargo o mapa codicolóxico de Díaz y Díaz amósasenos desolado para o espacio portugués. ${ }^{9}$ Para Galicia, tamén rica en exemplos pero pobre en exemplares (apenas un fragmento de seis follas, hoxe desaparecido ${ }^{10}$ ) alomenos conservamos documentos de doacións que mencionan a entrega de códices concretos, e de feito, dos cinco documentos deste tipo que temos atopado, catro corresponden ó territorio galego e só un á zona asturiana. ${ }^{11}$

destino á Narbonense e ós seus hispani», p. 222. A isto hai que engadir o éxito que tivo o Liber na Cataluña do XI cando, da man de importantes coñecedores da Lex como Poncio Bonifilio ou Homobono, entrou como texto esencial na ensinanza das escolas catedrais e nalgúns mosteiros, incrementándose a producción de exemplares ata o punto de plantexarse Y. GARCÍA a existencia dun monopolio editorial do Liber en Barcelona dende inicios do XI (para isto, ver todo o capítulo que a autora adica ó que ela chama «Floruit y expansión del Liber en Cataluña. s. XI. «) Por desgracia, non se pode seguir un movemento desta magnitude no reino de León.

${ }^{9}$ Poderiamos ter a tentación de usar para cubrir este valeiro o fragmento que se conserva na Biblioteca Municipal de Oporto como unha das gardas dun códice de San Agustín. Pero DÍAZ Y DÍAZ non dubida en afirmar a súa orixe pirenaica e dátao no século IX. "Se non me engano, é o fragmento da Lex máis antigo que se conserva en toda a península”. M. C. DÍAZ Y DÍAZ, Códices visigóticos en la monarquía leonesa, León 1983, pp. 434-435. Tamén tentando encher o valeiro portugués, en canto a códices se refere, pódense ver as dúas alusións que DA COSTA recolle: en 1187, na reunión de Tui, o arcebispo de Braga alegou contra o de Compostela, entre outras probas, «libros duos quos dixit Judiciorum libros»; e en 1393, no inventario da biblioteca da Sé de Coimbra, cítase un «Livro dos juizes dos Godos». A. DE JESÚS DA COSTA, «Fragmentos preciosos de códices medievais», en Estudos de cronologia, diplomática, paleografia e históricolingüisticos, Porto 1992, pp.95-96. Pero o certo é que, hoxe, non se coñece ningún exemplar do Liber para Portugal.

${ }^{10}$ Este fragmento é o que dá pé a OTERO VARELA ás súas reflexións sobre a pervivencia do Liber trala caída da monarquía visigoda, "El códice López Ferreiro del Liber Iudiciorum", en A.H.D.E. 29 (1959), pp. 557-573.

${ }^{11}$ Trátase dos documentos de Celanova de 889 e 938, de Samos de 967 e de Lalín de 1019. O asturiano é de 1045.

"CUADERNOS DE ESTUDIOS GALLEGOS", Tomo XLIV, Fascículo 109, Santiago 1997. 
De tódolos xeitos, esta non deixa de ser unha tentación un tanto fetichista: a conservación ou non destes exemplares depende de tantos factores (e o azar non é o menor deles), que non podemos axeitar a imaxe que nos fagamos sobre o uso do Liber en León simplemente ó que a distribución destes supervivientes nos insinúe ${ }^{12}$. Outra cousa é, claro, lamentar a perda da información que cada exemplar en concreto nos ofrece sobre as súas influencias e o seu uso (modelos que segue, manipulacións identificables, anotacións marxinais e glosas, etc.), pero a historia da pervivencia deste código non se pode queixar precisamente de deixar poucas testemuñas, tanto directas como indirectas, se así se poden considerar as referencias documentais. E estas últimas serán o eixo do noso traballo.

\section{A PERVIVENCIA DO LIBER: UNHA CONVICCIÓN XERA- LIZADA}

Pretender asombrar coa afirmación de que o Liber Iudicum mantivo a súa vixencia máis aló do 711 non é un bo punto de partida. A permanencia do Liber como código de referencia legal ata, alomenos, o século XII é algo máis que comprobado para os reinos cristiáns que viñeron ocupar o espacio (xeográfico e político) do reino visigodo. Dende a historia do dereito, dende a filoloxía, dende a historia, as investigacións que dun xeito ou doutro inciden sobre esta continuidade non son poucas, e a diversidade das súas abordaxes reforza esta convicción xeralizada na historia posvisigoda da Lex Wisigothorum. O noso traballo vese así arroupado dende outras disciplinas: os historiadores do dereito, deixando de lado outro tipo de discusións, coinciden todos en considerar o código legal visigodo como o marco de referencia xurídica altomedieval, sobre o que se irían producindo as modificacións e os axeitamentos necesarios, de acordo coas novas circunstancias políticas e sociais. Á súa vez, os filólogos, arrincando da propia materialidade do Liber como obra escrita, lida e manexada, e non limitada á súa natureza xurídica, póñennos en contacto directo co uso do código como códice nos séculos posteriores a desaparición do reino godo.

\footnotetext{
${ }^{12}$ Que quede claro que na zona catalana, a maior presencia de manuscritos tamén ven acompañada doutros indicios (vid. n. 8).
}

"CUADERNOS DE ESTUDIOS GALLEGOS", Tomo XLIV, Fascículo 109, Santiago 1997. 
En canto ós historiadores, xa se teñen achegado tamén a este tema ou o teñen tocado de forma lateral. Eu salientaría en especial os diferentes artigos de Roger Collins, tanto cando se adica á analise da literacy ${ }^{13}$ como cando se centra na resolución das disputas e dos pleitos nos reinos cristianos do norte ${ }^{14}$; en ámbolos dous casos incide de forma constante nesa pervivencia de formas de facer visigodas. ¿Pero cal é, entón, o obxetivo que nos propoñemos neste estudio? Basicamente dúas cousas: en primeiro lugar, facer unha recollida sistemática dos datos documentais que certifiquen, dunha forma ou doutra, que esa pervivencia do Liber, para o reino de León, é algo máis ca unha impresión xeralizada ${ }^{15}$; e, en segundo lugar, analizar eses datos coa intención de calibrar e calificar o sentido exacto desa pervivencia, é dicir, intentar ver qué tipo de coñecemento do Liber transparentan as citas e alusións recollidas, e quén, cándo e cómo recurría a el.

\footnotetext{
${ }^{13}$ Este recente tema historiográfico conta xa cunha aportación de peso para o ámbito hispano altomedieval, tanto visigodo como omeya e cristián do norte; refírome ó artigo de R. COLLINS que se cita na n. 5. Neste artigo, R. COLLINS trata, entre outras, a figura do xuíz cristián altomedieval e a súa relación cos códices que contiñan a lex, para apoiar a idea dunha literacy laica. As súas conclusións sobre a figura do xuíz, sobre a posible inexistencia dunha formación "profesional" xurídica, sobre o sentido da utilización das citas do Liber, sobre as características dos códices empregados, etc., son eixo importante para calquera discusión sobre a incidencia social deste código.

${ }^{14} \mathrm{O}$ seu interese polo valor do rexistro escrito lévao a redactar, nas conclusións da obra colectiva The Settlement of Disputes in Early Mediaeval Europe, Cambridge 1986, a parte adicada ó papel da escritura na resolución e rexistro dos pleitos, pp. 207-214. É nesta obra onde inclue "Visigothic law and regional custom in disputes in early medieval Spain", un estudio dos pleitos altomedievais baixo a influencia da lei visigoda, como xa fixera antes en "Sicut lex Gothorum continet: law and charters in ninth- and tenth- century León and Catalonia", en The English Historical Review, CCCXCVI (1985), pp.489-512.

${ }^{15}$ Como base de partida coa que se iniciou este traballo, contabamos coas listas feitas a pé de páxina en: HENRIQUE DE GAMA BARROS, História da Administraçto Pública em Portugal nos s. XII a XV, I, Lisboa 1945., pp.6-8; a de C. SÁNCHEZ-ALBORNOZ en «Alfonso III y el particularismo castellano», en C.H.E. 13 (1950), p. 67, n. 16, e a de J. RODRÍGUEZ FERNÁNDEZ en Los fueros del reino de León, I: Estudio crítico, León 1981, pp. 43-47, n. 48, así como, sen ser propiamente relacións documentais, aquelas referencias citadas en diferentes obras e artigos. O resultado, logo de baleirar un amplo grupo de fontes editadas do reino de León, foi un conxunto de 150 documentos que se incluiron (en rexesto e cos extractos concretos da referencia á Lex ou ó Liber ) como apéndice na miña tesiña de licenciatura A Lex Gótica e o Liber Iudicum. O seu uso e coñecemento ó traverso dos documentos do Reino de León (s. IX-XII), dirixida polo prof. F. LÓPEZ ALSINA.
}

"CUADERNOS DE ESTUDIOS GALLEGOS", Tomo XLIV, Fascículo 109, Santiago 1997. 
É por iso que Michel Zimmermann é un autor de referencia, porque este labor que nos propoñemos aquí foi feito xa por el para o ámbito catalán: «Nós desexamos apreciar o aspecto cultural desta permanencia visigótica. ¿Como se manifesta? ¿Que nivel de coñecemento real da Lei prova? ¿Que tipo de utilización prolonga este coñecemento? ¿Que significación pode ter en Cataluña na época que nos interesa?» ${ }^{16}$. A ampla recollida das citas, así como un axeitado criterio clasificatorio, unha identificación -cando for posible- das leis citadas e a valoración das diferentes formas de aludir á Lex, foi a base sobre a que este autor tentou distinguir se as leis eran citadas explicita e conscientemente, se se facía só como alusión a un principio de autoridade, se só eran frases ocas, puros formulismos, se detrás existían razóns xurídicas ou culturais, etc, en fin, cómo se concebía a lei gótica cando se acudía a ela, se é que de verdade se sabía o que se estaba facendo. Esta será a liña a seguir agora para o Reino de León.

\section{METODOLOXÍA: CRITERIOS DE SELECCIÓN E CLASIFI- CACIÓN}

¿Cal foi o criterio para seleccionar os documentos? A condición esencial é que a Lex ou o Liber estean presentes e nos permitan pescudar sobre como se concibe, no propio documento, esa referencia, alusión ou simple pegada inconsciente; porque se algo está claro é que existen diferentes xeitos e graos de uso desa tradición visigótica na documentación altomedieval. As "tipoloxías" que M. Zimmermann usa para facer esa clasificación son moi claras e útiles, e aplicables tamén fóra do mundo catalán ${ }^{17}$; el fala de catro formas de aparición da Lex nos documentos:

\footnotetext{
${ }^{16}$ M. ZIMMERMANN, "L'usage du droit wisigothique en Catalogne du IX" au XII" siècle: Aproches d'une signification culturelle", en Melanges de la Casa Velázquez, 9 (1973), p. 235. Xa o título nos dá idea de cal é a orientación da análise. Engade ademais cando fala dos diferentes tipos de citas da Lei: “E por último está o uso da Lei nun proceso xudicial ou testamentario, sen que a Lei sexa citada nin evocada máis que por expresións ou fórmulas que lle son tomadas prestadas. Tocamos aí con problemas da práctica do dereito, que temos que deixar de lado para limitarnos á cuestión da cultura", p. 238.

${ }^{17}$ ZIMMERMAN, op. cit. pp. 237-238.
}

"CUADERNOS DE ESTUDIOS GALLEGOS", Tomo XLIV, Fascículo 109, Santiago 1997. 
-a máis chamativa é a cita explícita da Lex, que deixa ver un claro interés (ben do redactor, ben da parte vencedora do pleito, ben do propio xuíz) pola rigurosa identificación da lei á que se recurre, xa que aparece introducida coa especificación do libro, título e sentencia: «Proinde invenimus in liber $V^{o}$ titulo VII ${ }^{o}$ sentencia VIII ${ }^{a}$ ubi dicit: si quis ingenuиm a servitium adicere voluerit ipse doceat quo ordine ei serviturus advenerit,... ${ }^{18}$. Que esta numeración non coincida exactamentẹ, ás veces, coa que propón Zeumer, non ten que ser causa de desconfianza: Manuel C. Díaz y Díaz e Yolanda García insisten en que en cada códice a tradición calla dunha forma particular, por ser esta unha obra de tradición aberta. A identificación pode ser resultado dunha lectura errónea do códice, pode ser debida a un erro na redacción do documento ou pode ser un rexistro exacto da colocación da lei no exemplar concreto que se estea a seguir.

-a referencia á lei (M. Zimmermann fala de "rappel de la Loi") como principio de autoridade, isto é, respaldando un acto, manifestando a vontade das partes, dando valor á decisión dun xuíz, amenazando calquera intento de infracción, etc. Trátase de reforzar o valor do documento ó traverso dese referente de legalidade, sen pretender remitir a unha estipulación concreta do Liber, con expresións do tipo «...sicut lex gotorum docet...», «...sicut lex godica ordinaverat...», «...quod nos lege ordinare...», «...quod liber iudicum precipit...», ata expresións máis elaboradas, como unha que tivo especial éxito na zona de Coimbra e Lorvao de mediados do X a mediados do XI: «...ut adimplere lex quod gloriosi principes nostri constituerunt una cum ortodoxis viris illustris presago spiritus plene cale rectis proculdubio declararunt...» ${ }^{19}$, e que tamén nos pon en aviso da posible fosilización formulística.

-a cita máis ou menos exacta dunha lei, pero sen que se indique que se trata da Lex gótica. Como pode reducirse a unha pequena frase, mesmo a

${ }^{18}$ É o exemplo de Braga de 1025 (J.M. FERNÁNDEZ DEL POZO, «Alfonso V, rey de León», doc. X, en León y su historia V, León 1984), interesante porque cita tamén explicitamente dúas leis máis. Deste tipo pódense ver os 37 exemplos que se indican no cadro coas denominacións da Lex.

${ }^{19}$ Non din atopado unha procedencia clara para esta construcción, pero é un bo remedo do estilo ampuloso do Liber, misturando ademáis conceptos relixiosos e políticos, aínda que non é este sitio para facer análises de estilo.

"CUADERNOS DE ESTUdiOS GALLEGOS", Tomo XLIV, Fascículo 109, Santiago 1997. 
unha fórmula, en especial se se trata dalgunha lei moi utilizada, ás veces o proceso de simplificación, e mesmo modificación, poden facer dubidar dos reais coñecementos do Liber de quen redacta o documento $;{ }^{20}$ exemplo claro disto pode ser a IV, $2,20^{21}$, que ten por idea central que «...quicquid homo ingenuus vir atque femina qui filios vel nepotes non relinquerit de omnia sua re faciat quod voluerit...», pero que pode acabar quedando en citas semellantes a pequenos refráns: «...hominis enim qui filium non abuerit faciendi de rebus suis quod voluerit...»; de todas formas esta lei, igual que as $\mathrm{V}, 2,6 \mathrm{eV}, 4,1$, a pesares desta tendencia a simplificarse, mesmo a misturarse ${ }^{22}$, como estas dúas últimas que tratan das doacións e das vendas, o mais normal é que veñan identificadas como leis do Liber: «...sic dicit in liber gotice valea donatio sicut et vendicio...», «...quomodo est licitum per Librum Iudicum ubi dicit donatio per scriptura facta semper maneat....»

-o último tipo de referencia á Lex é aquela que se deduce do propio procedemento xudicial (os trámites, as fases, os protagonistas, os métodos de proba, etc.) ou do seguimento de certas prácticas de rexistro documental (testamentos, doacións, vendas, etc.), na medida en que a aplicación do dereito godo conformara uns modelos que non se abandonaron, isto é, a pervivencia da Lex gótica en sentido estricto. Este uso da Lei provoca ás veces a aparición nos documentos de conceptos, expresións ou fórmulas sacadas da bagaxe terminolóxica visigoda: assertor, conditiones sacramentorum, pena caldaria, mesmo tiufadus, etc.

Compre agora, sobre esta tipoloxía, explicar cales foron os criterios da escolla: os documentos seleccionados e que serviron de base para este estudio son aqueles nos que existe unha consciente chamada á Lex, ben específica e rigurosa como amosan os do primeiro tipo (citando a lei coa indicación de libro, título e sentencia), ben simplemente como recurso de

${ }^{20}$ ZIMMERMANN di que "estas alusións non implican necesariamente un coñecemento profundo da Lei. Poden non testimoniar máis que unha memoria colectiva. E non sendo así, ¿a que nivel cultural se debe?: ¿ó do escriba?, ¿ó do donatario?”, op. cit. p. 238.

${ }^{21}$ A numeración e identificación das citas faise pola edición de ZEUMER.

${ }^{22}$ Por poñer un exemplo claro de mistura de leis, véxase o doc. de Porto de 1068: “...in liber godorum doctores sanserunt et in canoniga sententia demostraverunt donatio que per vim ne metum non fuerit extorta talem qualem hemctio abeat firmitatem", onde o redactor emprega terminos sacados de V,2,1 e V,4,1.

"CUADERNOS DE ESTUDIOS GALLEGOS", Tomo XLIV, Fascículo 109, Santiago 1997. 
autoridade. Non incluín, por contra, aqueles outros que recollen fórmulas tiradas do propio Liber, ou das coñecidas Fórmulas Visigóticas, pero que perderon xa a consciencia desa procedencia, fixándose como parte da estructura diplomática e desplazando á súa función de fóra a dentro do documento; refírome a algunhas expresións amplamente difundidas nos documentos altomedievais: o encabezamento de II,1,2 «Quod tam regia potestas quam populorum universitas...», que se empregou en situacións diversas, con leis diferentes, como proclamación da aplicación xeral dun precepto, xa que nesta lei se recalca a obriga do propio rei a someterse ás mesmas leis que o pobo ${ }^{23}$; a construcción «Magnus est enim titulus donationis in quo nemo potest actum largitatis inrumpere...» sacada das Fórmulas Visigóticas ${ }^{24}$; ou as expresións que teñen a función de garantir a voluntariedade do acto rexistrado, en relación coas leis do libro $\mathrm{V}$, título 2, «Placuit nobis atque convenit nullius cogentis imperio neque suadentis articulo sed propia et spontanea voluntate ut venderemus vobis...», etc. ${ }^{25}$

Tampouco crín necesario incluír os documentos que nos falaban da Lex gótica ó traverso da súa práctica, é dicir, aqueles que, por estar rexistrando o desenvolvimento dun proceso xudicial ou por ser o rexistro dunha venda, doación ou permuta, nos poden remitir, sen ningunha indicación explícita, a calquera lei do libro II (De negotiis causarum), que trata sobre os litixios, os xuíces, as testemuñas, os sistemas de proba, as escrituras, etc., ou a calquera lei do libro V (De transactionibus), onde se estipulan as formas de tramitar doacións e vendas. Ademáis de que sería

${ }^{23}$ Exemplos do uso desta expresión son doados de atopar, pero se se desexa pódense ver os que J. RODRÍGUEZ recolle (op. cit., pp. 51-52). Como é de esperar, sobre esta construcción central as modificacións e engadidos son tamén frecuentes.

${ }^{24} \mathrm{Na}$ edición que destas Fórmulas fai J. GIL en Miscellanea Wisigothica, Sevilla 1972, pódese atopar, para este caso concreto, unha pequena relación de documentos que inclúen este encabezamento (pp. 100-101). De todos xeitos, si se pode ver algún caso no que esta construcción vai seguida dunha referencia ó Liber; así, os docs. de Santiago de León de 1028, de Porto de 1068, de Braga de 1072 e 1077, de Pendorarda de 1080, etc.

${ }^{25}$ Sobre estes formulismos pódese ver as reflexións de J. RODRÍGUEZ, op. cit. pp.51-55. En xeral, só cabe estar de acordo con A. PRIETO MORERA, que non deixa de queixarse de que aínda non está feito un estudio diplomático a fondo do documento altomedieval, tal e como afirma en "El proceso en el reino de León a la luz de los diplomas", en El reino de León en la Alta Edad Media, II: Ordenamiento jurídico del reino, León 1992.

"CUADERNOS DE ESTUDIOS GALLEGOS", Tomo XLIV, Fascículo 109, Santiago 1997. 
unha labor inxente, en certo xeito xa está feita (para o reino de León en xeral) no que se refire ó proceso xudicial: a forma na que Prieto Morera organiza a súa exposición lle permite ir relacionando, á pé de páxina, os exemplos máis significativos para cada fase do procedemento, dende a constitución do tribunal, ata a sentencia e a agnitio, pasando pola formalización da querella, a comparecencia do demandado, os alegatos, o establecimento das probas, etc. nun constante cotexo co que serían os modos visigóticos.

De todas formas, e como os "documentos procesais" si teñen unha presencia importante entre os que acabaron constituíndo o material de este traballo, compre salientar a pertinencia das observacións que o mesmo PRIETO MORERA fai sobre este tipo de documentos: na gran maioría dos casos a información procesal ven da man de diplomas (ben orixinais, ben copias en tumbos) que garantizan unha propiedade inmoble (con frecuencia para a institución eclesiástica) e non de actas propiamente xudiciais; pero estes diplomas conteñen ás veces noticias procesais tan completas, de xeito que parecen estar próximos ó desenvovimento do litixio: quizais por mor da falta de práctica do redactor do documento, parece como si nestes diplomas se seguira moi de perto a redacción dunhas posibles actas do pleito, transcribindo alegacións, xuramentos, sentencias, etc. ¿Pero qué tipo concreto de documentos estarían a copiar? Prieto Morera cree que non eran exactamente sentencias ou agnitiones (isto é, recoñecemento de pérdida do pleito), senon un tipo novo de documento, o que el chama plácito de aseguramento do resultado procesal, polo cal a parte vencida, ou as dúas partes, comprometíanse a aceptar e cumplir o resultado (podían ser plácitos de aseguramento de sentencias, plácitos de aseguramento de agnitiones, plácitos de aseguramento de avenencias); así se entenderían, por exemplo, as dificultades para seguirmos a liña do proceso nun destes documentos, xa que o redactor constrúe este plácito entresacando a información das actas do proceso, sen que prime, precisamente, a coherencia sintáctica. ${ }^{26}$

${ }^{26}$ Todas estas observacións atopámolas en A. PRIETO MORERA, op. cit., pp. 386394. En canto á dificultade que plantexan alguns documentos para seguir ó seu traverso o desenvolvemento dun pleito, pódese ver os intentos de COLLINS por clarificarnos o que enfrenta ó mosteiro de Celanova cos habitantes da villa de Zacors en 987 ( «Visigothic law and regional custom...», pp. 89-90)

"CUADERNOS DE ESTUDIOS GALLEGOS", Tomo XLIV, Fascículo 109, Santiago 1997. 
Así seleccionados, pois, estes documentos conformaron a base do noso estudio.

\section{A LEI: USO XURÍDICO / USO «CULTURAL»}

A Lei e o Libro aparecen nas citas coa mesma frecuencia: Lex gotica e Liber son, como se ve na táboa de denominacións, os dous puntos de referencia sobre os que se fai esa chamada: lex simplemente ${ }^{27}$, lex godica, lex gotorum, leges pacíficas, liber iudicum, liber iudiciale, liber godorum, liber gotice, simplemente liber... Non se pode pensar nunha separación entre ámbalas dúas ideas ${ }^{28}$ : a lei como código e a lei como códice teñen a mesma forza lexitimadora, o mesmo poder validador, son a mesma cousa: cando se consulta o libro, estase a consultar a lei, e cando se fai referencia á lei, é a imaxe do libro a que se presenta... Pero ¿cal era exactamente o uso que se facía dese poder?

Creo que non hai un único uso, unha única actitude respecto á presencia da Lei nos documentos. Zimmermann solvéntao falando de dous niveis de utilización:

-un uso práctico-xurídico, no que a rigurosidade na cita dunha lei concreta, coa súa identificación explícita (libro, título, lei), nos fala do interés por apoiar na lei un procedemento determinado ou unha decisión xudicial con tódalas garantías posibles; sería o uso máis vivo da lei porque esta necesitaría adaptarse ás novas condicións, ás novas esixencias, ou

\footnotetext{
${ }^{27}$ Cando só aparece o termo lex, sen ningún outro calificativo, poderíase pensar que non ten porque existir a identificación lex = lex gótica. Sen embargo, documentos como os de Guimarães de 959 e 999, Sobrado 960, Coimbra 1013, Otero de las Dueñas 1018 e 1022, León 1023, etc. poden servir para ver como non era necesario facer tal identificación explícita. Por outra banda, cando existiu a certeza (ou só algunha dúbida) de que o termo lex se refería á Biblia, á lei sagrada, o documento non foi incluído no apéndice da tese de licenciatura.

${ }^{28}$ Mesmo nalgúns casos se reforza coa súa aparición conxunta: «...quomodo est licitum per Librum Iudicum et lex Gotorum ubi dicit commutatio per scriptura facta semper habeat roborem...» se di en Braga en 1113, ou a expresión «...placido pro inquirere lege de libro: Si quis aderibiendum...» que aparece no doc. de Otero de las Dueñas de 1019, ou de forma máis clara o doc. de San Millán de 940: «Et mandavit legem et libro Iudicum...» Os exemplos desta identificación multiplícanse.
} 
simplemente ser adaptada e recortada polo escriba para colocala no documento. ${ }^{29}$

-un uso "cultural", onde o que se aproveita non é a lei como fonte de decisións xudiciais senon como autoridade moral, como expresión da aceptación dunhas normas e formas de facer, como recoñecemento da existencia dun referente legal que normaliza as relacións dentro da comunidade; en realidade esta é a explicación que Zimmermann lle dá á multiplicación de citas dunha mesma lei que parecen facerse sitio na documentación da época sen que estean a reflexar un uso directo do Liber: el refírese a leis como V,2,6 (De rebus traditis vel per scriptura donatis) ou V,2,1 (Non valeat violenter facta donatio), que tenderían a fixarse como fórmula, a perder a súa conexión consciente co Liber, a redactarse de xeito máis conciso, ás veces mesmo a modo de refrán, a modificarse e misturarse con outras leis (por exemplo, as amalgamas entre $\mathrm{V}, 2,1 \mathrm{e} \mathrm{V}, 4,1$ ), etc. A Lei como precepto ético, chega a dicir o mesmo Zimmermann. ${ }^{30}$ Unha ou outra tendencia van estar polarizando o sentido de uso en cada documento; e como vai ser con estes cos que traballemos, creo que sería interesante tentar levar esta dicotomía a outro nivel, ó nivel da propia construcción do documento: ¿en que momento, das distintas fases que podemos rastrexar nun documento, se incorpora esa cita ou esa referencia á Lex? As opcións, creo, son dúas:

-que a cita sexa buscada e feita no momento do proceso $^{31}$, incluída

\footnotetext{
${ }^{29}$ Por poñer un exemplo claro desta utilización "xurídica" da lei, basta ver o doc. de Braga de 1025; alí, o xuíz Eyta Fortuniz emprega o Liber en tres ocasións para encarrilar o proceso: primeiro citando $\mathrm{V}, 7,8$ (sobre os libres demandados por servos, e os servos que se din libres) para centrar o caso, un pleito entre o bispo de Braga e un grupo de servos que se declaran inxenuos; e logo citando II, 1,3 (que o xuíz primeiro interroge ás partes, comprobe as escrituras e só despois, se fose necesario, recurra ó xuramento) e II,4,5 (que os testigos deben declarar en persona e non por cartas) para fixar o procedemento. É de resaltar neste caso, ademáis da rigurosidade e conveniencias das citas, que estas se fagan completas, ou casi, e non simplemente o enunciado da lei (que, de feito, xa non se recolle). Non é de extrañar que, orgulloso, Eyta Furtuniz subscriba como "qui iudicavit et omnia per verifice ordine exaravit conf." Tamén servirían de exemplo os de León 952, Vacariza 1040, Guimarães 1053, Celanova 1054, Sahagún 1059, Oviedo 1075,...

${ }^{30}$ Estas reflexións de ZIMMERMANN sobre os dous usos da lex pódese ver en op. cit. pp. 255-259.

${ }^{31}$ Ben antes ou despois da sentencia, isto non está totalmente claro: tanto é posible que se resolva o caso buscando a solución no Liber, como que, xa sentenciado polo(s) xuíce(s), o beneficiado se interese por recoller a cita do Liber que basea esa sentencia, para
}

"CUADERNOS DE ESTUdIOS GALLEGOS", Tomo XLIV, Fascículo 109, Santiago 1997. 
logo nas actas ou no plácito de aseguramento, e por último no documento que hoxe conservamos (ou a súa copia no cartulario). Serían, sobre todo, os documentos «procesais».

-ou que, segunda posibilidade, non existindo propiamente un litixio, se trate só dunha doación ou venta, ou dunha herdanza, e que a Lex se empregue para dar validez a este título de doación (ou do que for, pero case sempre garantindo unha propiedade inmoble), ben incluíndo unha referencia á IV,2,20 (que xustifica o dereito a doar o que se desexe cando non se teñen herdeiros directos), a $\mathrm{V}, 2,6$, a $\mathrm{V}, 4,1$ ou a $\mathrm{V}, 1,1^{32}$ no encabezamento ou no tenor do diploma, ou ben lembrando o poder punitivo da Lei, no caso da súa infracción, na cláusula final das penas xudiciarias. Neste caso, a presencia do Liber deixa de ser o reflexo dunha presencia física, material, tanxible nalgunha fase do proceso, para se convertir nunha das partes constitutivas do diploma dende a súa creación (formando parte máis da diplomática do documento que da súa historia), sen que o Liber, como códice, xogase algún papel.

É evidente que a maior riqueza (tanto en diversidade como en rigurosidade) vai vir da man dese primeiro tipo de citas, porque dependendo da complexidade do litixio e da dispoñibilidade dun Liber, e dalguén coas inquietudes suficientes como para atreverse co dificultoso estilo da obra, así se aproveitará a potencialidade dun código que abrangue, co seu sentido de totalidade, os mais diversos campos susceptibles de seren lexislados e reglamentados. Quede claro que tamén hai que incluír neste nível, máis

reforzar así o poder disuasorio do título; malia que na nosa cultura xurídica sexa irracional sentenciar primeiro e buscar a lei despois, esta é unha actuación contrastada antropolóxicamente: «Nos procesos negociados, e nos de xudicación, os disputantes e as terceiras partes organizan os seus argumentos ó traverso das proposicións normativas. Estas poden ser máis ou menos explícitas e definidas, e ser inverosimilmente ríxidas na determinación do resultado; pero darán forma ós argumentos e terán algún papel no resultado obtido (...) O xuizo pode ser ad hoc e o resultado negociado ser presentado no idioma da norma.» S. ROBERTS, «The study of dispute: Anthropological perspectives», en Disputes and settlements. Law and human relations in the west, ed. J. BOSSY, Cambridge 1983, p. 14.

${ }^{32} \mathrm{~V}, 1,1$ : aínda non fixen ningunha alusión a esta lei, pero tamén é citada con frecuencia xa que regula as doacións feitas á Igrexa (a súa conveniencia non pode ser máis clara). Véxanse os docs. de Oviedo 1058, Braga 1101, 1103 e $1105 \ldots$

"CUADERNOS DE ESTUDIOS GALLEGOS", Tomo XLIV, Fascículo 109, Santiago 1997. 
próximo ó proceso que ó documento final, aquelas outras chamadas á Lei polas cales as partes aceptan someterse ó seu dictado, á súa autoridade («ut presentemus nos in presentia iudicis et accipiamus veritatem quod nos lege ordinat...», «et quod nos lex iusserit adimpleamus...», «iurare devemus si lex ordinare...»), ou simplemente calquera outra referencia á Lei feita no ámbito do proceso, sen que implique necesariamente unha cita, e que normalmente ten a intención de deixar claro que o proceso se está a facer correctamente, seguindo a Lei.

En cambio, a outra abordaxe do Liber tende a se centrar na súa compoñente diplomática, isto é, condenándose a unha progresiva fosilización formulística; de todos modos, non creo que esta tendencia teña que identificarse cun esquecemento da orixe da súa fonte: a pesar das reduccións e modificacións que poidan sufrir as leis citadas, normalmente seguen levando a súa identificación como Lex Gotorum ou a súa procedencia do Liber Iudicum; ademais compre ter en conta que, aínda que non rexistrados por motivos que se tentarán ver, o Liber debeuse seguir usando en máis procesos dos que hoxe temos noticias ata aínda ben entrado o século XII, de xeito que non sería tan doado ignorar esa tradición visigótica.

Pero empecemos polo máis chamativo: ¿cales son as leis se citan?

\section{LIBROS E LEIS CITADOS}

Sen necesidade de recurrir a todas estas clasificacións sobre usos, formas e tipos de alusións á Lex, esta claro que existe unha diferencia básica entre uns documentos e outros, tal e como se pode obsevar de un simple vistazo ó apéndice: nuns casos é posible identificar (con maior ou menor dificultade) á que lei concreta se está a facer mención, ben porque de forma explícita se indique o libro, título e sentencia, ou ben porque só se cite parte da lei ou se resuma a súa idea central; e isto abranguería tanto mostras dese uso xurídico como tamén mostras do uso «cultural». E fronte a estes casos, están aqueles outros nos que a apelación á Lex é global, sen concretar unha sentencia determinada, senón como referencia de autoridade que as partes acatan e que garante o recto desenvolvemento

"CUADERNOS DE ESTUdIOS GALLEGOS", Tomo XLIV, Fascículo 109, Santiago 1997. 
do negocio (sexa un litixio, sexa unha venda ou doación). ${ }^{33}$

Isto lévanos á necesidade de facer un primeiro paso logo da recollida dos testimonios: o da identificación das leis concretas das que os xuíces (ou os redactores) botaron man, coa intención que for, e que nos permite tentar avaliar a continuidade de intereses e o grao de vixencia da herdanza visigótica. O proceso de identificación que levou a elaborar a táboa II permítenos seguir esta análise, que non pretende ser casuística, e que nos pon en contacto co aproveitamento leonés do saber xurídico godo.

O que primeiro chama a atención é que as $\mathbf{5 8 0}$ leis do Liber están pobremente representadas, sen que nin sequera haxa un equilibrio na utilización dos doce libros: os libros II, IV e V, e, en menor medida, o III, son os que concentran o maior número de leis identificables; de feito, só se vai máis aló do libro $\mathrm{V}$ en media ducia de casos.

Que non se cite para nada o libro I é razonable, tendo en conta o seu carácter teórico e xeral, pouco aproveitable dende un punto de vista xurídicopráctico, e excesivo como marca de autoridade. ${ }^{34} \mathrm{E}$ que o libro II, pola contra, teña unha presencia máis sólida tampouco debe sorprendernos demasiado: pola súa temática, ten que ser de coñecemento obrigado ${ }^{35}$ para quen desempeñe funcións de xuíz, porque as disposicións que recolle regulan de forma minuciosa a actividade xudicial, sendo nese ámbito, no do desenvolvemento do proceso, onde se van xerar grande parte das alusións ó Liber. Se se tiveran incluído neste traballo tódolos documentos que reflexan a permanencia de prácticas legais godas ${ }^{36}$, sen mención á súa

${ }^{33}$ Dos catro tipos de alusións á Lex que M. ZIMMERMANN propón (1. cita explícita, 2. referencia de autoridade, 3. cita non explícita e 4. reflexo dunha práctica recollida polo Liber) neste traballo só se incluiron os tres primeiros, como xa se explicou. E destes tres tipos, o 1. e o 3 . son os que permiten identificar leis concretas, mentres que o 2. abranguería o resto dos casos.

${ }^{34}$ «Teño para min que a ineptísima serie de principios escolares que constitúe o actual libro I non pertenceu ás primeiras compilacións legais, senon que se engadeu despois cando, entre outras razóns, xa non pareceron suficientes as bases positivas de 2,1, 2.3.4. [...] Nese momento [coa nova edición de Ervigio] debeuse organizar o libro I, e penso que como unha especie de simple recheo para obter un efecto determinado, o de acadar no corpus visigótico o mesmo número de libros que compoñen o Codex». M. C. DÍAZ y DÍAZ, op. cit. pp. 205-206.

${ }^{35}$ Isto é matizable, dende logo; de todas formas, vai ser máis adiante que nos centremos no relacionado co coñecemento e estudio do código legal visigodo, así como na posible existencia de personaxes especialmente peparados neste sentido.

${ }^{36}$ É dicir, se se tivera pretendido facer un traballo de Historia do Dereito visigodo no reino de León.

"CUADERNOS DE ESTUDIOS GALLEGOS", Tomo XLIV, Fascículo 109, Santiago 1997. 
orixe (isto é, o tipo 4. de Zimmermann), este libro II acapararía a meirande parte das referencias. Pero aínda non os incluíndo, o recurso ós títulos 1 (sobre os xuíces), 4 (sobre as testemuñas) e 5 (sobre os testamentos) fala da pertinencia das súas normas: modélico é, neste sentido, o documento de Braga de 1025, onde o xuíz Eyta Furtuniz artella o pleito citando II,1,3, sobre a orde das probas, e II,4,5, sobre as testemuñas orais, aparte dunha lei do libro V ${ }^{37}$; ou o documento de Sahagún de 1067, onde o xuíz Petro Gonzalviz acude a II,4,3 para aceptar a validez de dúas boas testemuñas, para despois só citar outras dúas leis, xa sobre a materia do pleito (a usurpación dunha propiedade da Igrexa).

A primeira destas leis $(\mathbf{I I , 1 , 8})$ será o instrumento usado pola monarquía leonesa, e mesmo xa antes pola astur, para combatir as actuacións de rebelión e traición dunha forma contundente e, sobre todo, cargada da forza da lexitimación dun pasado godo co que esta monarquía estaba a querer entroncar. Isto nos levaría a outro nivel dentro desta pervivencia do Liber: ó nivel da súa funcionalidade política, como código promovido pola realeza dentro dunha recoñecida tendencia neovisigótica, que se pode comenzar a ver na tantas veces citada pasaxe da Albeldense, na que Alfonso III «omnemque Gotorum ordinem, sicuti Toleto fuerat, tam in eclesia quam palatio in Ovetao cuncta statuit», pero que sobre todo acada o seu punto culminante, no que á Lex se refire, coa noticia que nos dá o Silense: que Vermudo II «leges a Vambano principe conditas firmavit, canones aperire iussit», no que parece foi a única confirmación formal do Liber, e dos canones conciliares godos, no reino de León ${ }^{38}$. Esta confirmación era a única forma de facer lembrar a capacidade lexislativa do monarca nun momento no que non se lexisla sobre nada, e cando se faga (Fuero de León, no 1017, ou os decretos do Concilio de Coyanza, no 1050), o Liber aínda seguirá sendo o marco xeral de referencia.

${ }^{37}$ vid. n. 29.

${ }^{38}$ R. COLLINS, España en la Alta Edad Media, p. 301, onde o autor indica a posibilidade de que fora a fraxilidade inicial da súa subida ó trono (en especial, dúbidas sobre a súa lexitimidade), o que o inclinou a medidas de poder como esta, unha función en exclusiva real. Ademais, o progresivo incremento das citas do Liber no século XI ten o precedente deses catro documentos de Vermudo II que citan II, 1,8, como estamos a ver: León 992, Celanova 994, Celanova 995 e Otero de las Dueñas 1012 (este último é de Alfonso $\mathrm{V}$, pero a cita da lei que se recolle fora feita polo seu antecesor).

"CUADERNOS DE ESTUDIOS GALLEGOS", Tomo XLIV, Fascículo 109, Santiago 1997. 
En todo caso, as pretensións deste traballo cínguense a unha dimensión máis cotiá do uso Liber, de xeito que o seu papel, sen dúbida esencial, dentro de un posible «pensamento político» leonés non é obxeto de estudo nestas páxinas. Pero si compre centrarse no interese que os monarcas leoneses amosaron nunha das leis, a xa mencionada II, 1,8, sobre a rebelión e desobediencia contra o rei, aproveitando a experiencia que levara ós reis godos a lexislar e mesmo a tratar esta cuestión nalgún concilio; de feito, II, 1,8 relaciónase normalmente co estipulado no canón primeiro do concilio VII de Toledo, sobre o mesmo problema e coas mesmas medidas, sen que estea clara a anterioridade dun sobre outro. É máis, en cáseque tódolos casos que na táboa II aparecen citando esta lei, á alusión á lei gótica íncide tamén no seu tratamento canónico: «quidquid in sacratissimum canonem et godigam legem invenitur de revellionibus vel contradictoribus regis sive de fagultatibus eorum, sicut in libro secundo et in eius titulis constitutum vel exaratum a prioribus sanctis patribus scriptus ecce discernitur»(León 992), «Sicut canones sancti et lex gotica de talibus ordinat...» (Celanova 994), «lex kanoniga et gotorum ordina nobis de talis personibus et ministris infideles...» (Otero de Dueñas 1032), etc. ${ }^{39}$ A necesidade de dar unha resposta firme á sempre presente tentación de discutir o poder real, sobre todo en momentos de indefinición da transmisión deste poder, vese na lista de rebeldes que na documentación se recolle: Hermenegildus Petri no Salnés, os irmáns Tritoniz tamén en Galicia, Gundesalbus Veremudi no castelo de Luna, o conde Ablabel, Petro Fredenandi, Eicta Fosatiz, Rudericus Romaniz, Fernando Pelaiz,... Sen embargo, aínda que a lei permite os máis duros castigos (morte, decalvación, vaciado dos ollos, servidume, desterro...) só o documento de Otero de las Dueñas de 1019 recolle algunha delas; o resto céntrase de forma exclusiva na perda de tódolos bens, que pasan a disposición da vontade real, así como tamén inciden na cláusula de garantía que a lei recolle para aqueles que son beneficiados polo rei con estes bens expropiados ós rebeldes, «et cui donate fuerint ita perpetim potestate possideat» (Lugo 1029).

\footnotetext{
${ }^{39} \mathrm{~A}$ estreita relación que a lexislación e os cánones conciliares godos tiveron ata o 711, sobrepasa esta data e caracteriza a lembranza, pervivencia e uso que no reino de León se fai da herdanza gótica. En moitos documentos se rexistra este vencellamento, case identificación, ata o punto de chegar denominar a Lei como lex sancta.
}

"CUADERNOS DE ESTUDIOS GALLEGOS", Tomo XLIV, Fascículo 109, Santiago 1997. 
Se cadra sexa esta particularidade, a da xustificación dun título de propiedade que pode ser problemático, o que explique a fortuna desta lei, que, por outra banda, é o mecanismo legal do que dispoñen os monarcas para favorecer as lealdades en detrimento dos rebeldes. ${ }^{40}$ Segundo Prieto Prieto, este sería ademais o único caso que especializaría ó tribunal real fronte ó resto dos tribunais. ${ }^{41}$

E ó lado desta lei, vai ser II,5,12 o outro recurso exitoso do libro II. A fixación das catro formas de testar que alí se recollen (tres por escrito, dependendo de se o que testa suscribe xunto coas testemuñas, se só fai unha marca ou se é unha testemuña a que suscribe por el; e unha oral, ante testemuñas), reflexa unha riqueza que só nun dos documentos seleccionados se pode apreciar, xa que cita as primeiras liñas da lei (non a intitulatio, senón o texto mesmo); pero aínda así, faino saltándose o último procedemento, o oral; trátase da confirmación da doación que a condesa Gunterodo Gundemariz fixera á catedral de Oviedo, en 1075.

Sen embargo, o recurso a esta lei na maioría dos documentos céntrase, de forma especial, en destacar o periodo de seis meses que se estipula para dar a coñecer o testamento, normalmente ante o sacerdote (tal e como se recolle tamén en II,5,14). «Hec serie constructa per ordinacione defuncti ad mense uno quod defunctus obiit, infra menses VI sunt, et hec confictio facta sicut dicit in libro secundo, titulo $V^{o}$, sentencia XII vel tercia decima de Gens Gotorum», se escribe en León en 1049 para cumplir o testamento que Pelagio Citiz, ferido de morte por unha espada, encargou a súa muller e fillos. ${ }^{42}$

Cabería salientar o particular grupo que forman os tres documentos que na táboa II aparecen identificados como II,5,? ; os tres repiten a

${ }^{40}$ Sobre II, 1,8 en concreto céntrase J. ORLANDIS no seu artigo «Huellas visigóticas en el derecho de la Alta Edad Media», en A.H.D.E. 15 (1944), pp. 644-658.

${ }^{41}$ «As causas tratadas polo tribunal real son semellantes ás tratadas polo resto dos tribunais: cuestións penais e relacionadas coa propiedade inmoble. De atoparse algunha especialización, sería, entre as primeiras, tratar o tribunal real as causas por rebelión», A. PRIETO PRIETO, «La potestad judicial de los reyes de León», en El reino de León en la Alta Edad Media, II: Ordenamiento jurídico del reino, León 1992, p. 549, n. 189.

${ }^{42}$ É lástima que non se poida vislumbrar, para o reino de León, o progresivo control que a Igrexa catalana vai exercer neste terreno, ó monopolizar en determinados altares as confirmacións testamentarias por xuramento das testemuñas, no caso do testamento oral. M. ZIMMERMANN, op. cit., pp.262-263.

"CUADERNOS DE ESTUDIOS GALLEGOS", Tomo XLIV, Fascículo 109, Santiago 1997. 
mesma fórmula, con escasas variacións: «Et secundum leges pacificas ut testatio testatoris secundum quod testatum est, ita valeat «. Mentres que a idea da cita parece facer alusión á validez legal do testamento, mediante unha fórmula que lembra moito á que veremos para as doacións e vendas (seguindo $\mathrm{V}, 2,6$ e V,4,1), sorprende a súa fixación (hai máis dun século entre o documento de Triacastela do 919 e o da catedral de León de 1022), e sorprende, sobre todo, o emprego dunha denominación, leges pacificas, que só atopei noutro documento, o de Celanova de $909^{43}$. Denominación chamativa que nun deles, no de Santiago 919, mesmo ven acompañada dunha apelación tamén única: leges publicas.

O resto das leis deste libro que se citan, pero xa de forma máis esporádica, van tratar asuntos relacionados coa testificación, como a mención que no título VII das disposicións de Coyanza se fai de II,4,6 (De his qui falsum testimonium dicunt), ou o xa mencionado de 1025. Trátase daqueles documentos nos que, por algunha razón, se explicita o procedemento: no caso do pleito que ten o mosteiro de Sahagún en 1067, que se resolve no tribunal real en León, o xuíz Petro Gonzalviz parece ter particular interese en que sexan dúas testemuñas de calidade as que apoien as afirmacións da parte do mosteiro, como así se fai no xuramento que ten lugar na igrexa de Santa María.

Se seguimos co repaso polos libros citados, tampouco podemos deixarnos sorprender pola presencia importante do libro IV: de feito, é unha das súas leis, a IV,2,20 (Ut, qui filios non reliquerit, faciendi de rebus suis quod voluerit habeat potestatem), a que, con 25 aparicións, se nos mostra como o máis afortunado dos recursos á lei dos godos, imprensión que se incrementa se tratamos esta lei en unión con IV,2,18, (Qualiter hereditatem parvuli parentes adquesi podssunt) que, polo seu contido, enlaza coas razóns que explican o uso da primeira. Mentres IV,2,20 lexitima as libres doacións que fan aqueles que non deixan descendencia, IV,2,18 normaliza a disposición dos bens dos fillos mortos. Desta forma, e liberados das obrigas que os herdeiros naturais supoñen,

\footnotetext{
${ }^{43}$ Poderíase pensar que o que aquí inclúo como alusión á lex gótica non o sexa, e que máis ben teña que ver con algunha disposición conciliar: é posible. O certo é que non din identificado de xeito máis exacto a procedencia desta cita, case fórmula. E tampouco atopei ningunha relación coas Fórmulas Visigóticas que, como se poido ver máis atrás, era outra das posibilidades. Malia todo isto, creo que debe ter o seu lugar neste traballo.
}

"CUADERNOS DE ESTUDIOS GALLEGOS", Tomo XLIV, Fascículo 109, Santiago 1997. 
os doantes fan testamento dos seus bens a favor de quen eles desexen (isto é, á Igrexa). Así se xustifica, no pleito de 952, o testamento que en no $927^{44}$ fixera o matrimonio Arbario e María, e que agora enfronta ó mosteiro de Abellar, beneficiario daquela doación, con Velasco Hanniz, nun dos documentos sobre os que Sánchez-Albornoz tece a súa teoría da existencia dun xuício do Libro, xa no século X en León. ${ }^{45}$

Sen embargo, hai dúas particularidades que saltan á vista no tratamento de IV,2,20; unha delas é xeográfica: no século XI e principios do XII, tódolos casos cos que contamos (21 dos 25 totais) son de territorio portugués, da zona de Coimbra e de Braga, mentres que os catro que rexistramos para o século X son (aparte do leonés xa mencionado de 952) galegos: Celanova 972 e Samos 978 e 989. Esta concentración enténdese mellor se reparamos na segunda particularidade, esta de carácter funcional: só o documento de 952 é unha cita da lei feita durante un proceso; en tódolos demais casos trátase de doacións nas que a referencia a IV,2,20 actúa como cláusula garantizadora da liberdade e da vontade coa que os firmantes entregan os seus bens xa ó mosteiro de Samos, xa ó de Leza ou xa á sé de Braga. E aínda que nalgúns casos a identificación faise mesmo por libro, capítulo e sentencia (Samos 978, Coimbra 1013 ${ }^{46}, 1014,1032,1043$ e 1045), é patente o proceso de «formulización»: reducción progresiva do tamaño da cita, alteración do texto orixinal mantendo a idea central da lei, desaparición da referencia de orixe, incluso unha tendencia mnemotécnica

\footnotetext{
${ }^{44}$ No que, por certo, non se fai referencia a tal disposición. Edítao E. SÁEZ no mesmo volume que o pleito de 952: Colección documental del archivo de la catedral de León (775-1230). I (775-952), León 1987, doc. 72 (o pleito é o doc. 256)

${ }^{45} \mathrm{~A}$ este respecto, creo que a postura máis acertada é a que propón PRIETO MORERA: que a idea dun tribunal especial do Libro, para casos de apelación de sentencias, tal e como SÁNCHEZ-ALBORNOZ pretende atopar xa no século X, é un anacronismo; « ¿Pero a proclamación das partes de que se acollían ó que mandase o Libro pode interpretarse como acudir a un tribunal especial do Liber? Non o vexo claro. Mais ben parece que o seu significado é o obvio $<<$ de estar ó que a lei ordena $>>[. .$.$] é claro que proclamar estar$ disposto a facer o que a lei manda (nesta época ningunha outra lei coñecemos que o Liber) é unha fórmula dos plácitos de comparecencia, polo menos en materia penal», A. PRIETO MORERA, op. cit., pp. 446-447. A postura de C. SÁNCHEZ ALBORNOZ vese en «El juicio del libro en León durante el s. X», en A.H.D.E. 1 (1924), pp. 382-387.

${ }^{46}$ Este é ademais o único caso que recolle a lei ó completo: libro, título, sentencia, intitulatio e texto ata o final. ¿A quen lle pode extrañar, a estas alturas, que Adeita Furtuniz estea firmando como iudex, malia non ser un pleito?
}

"CUADERNOS DE ESTUDIOS GALLEGOS", Tomo XLIV, Fascículo 109, Santiago 1997. 
á formación de pequenos refráns, como xa se comentou ó definirmos os tipos establecidos por Zimmermann; así, se en Coimbra, no 1014, lemos «Qui dicit in libro iudicum -qui filium non relinquerit aut nepotes aut pronepotes de re sua licentiam habeat quod voluerit faciat- sicut invenimus in libro IIII $^{o}$ titulo II $^{o}$ sentencia XVIIII ${ }^{a} \gg$, en cambio en Moreira en 1089 xa temos «quia dixit in libro gutorum -omo qui semen non abet de rem suam faciat quod voluerit», e en Braga, no 1100, «sed quicquid omnis ingenuus faciat de omni sua re vel hereditate quod voluerit». A lei xa forma parte da estructura diplomática encabezando a carta de doación (e, ás veces, mesmo de venta ou intercambio), tal e como xa avanzamos no apartado sobre o uso xurídico e o uso cultural da Lei. Neste sentido, IV,2,20 amosa unha forte tendencia a encadrarse neste último, e IV,2,18 tamén, aínda que sen acadar o mesmo nivel de fixación formulística, nin tampouco limitándose á un único espacio xeográfico (un exemplo portugués, un galego, outro asturiano e dous leoneses forman este pequeno grupo).

E fronte á IV,2,18/20, este libro nos ofrece tamén a rentabilidade do grupo que forman IV,5,1 e IV,5,6, leis que, por temática e finalidade, sería mellor tratar de forma conxunta coas que integran o título primeiro do seguinte libro (V,1 De ecclesiasticis rebus). En certo xeito, a función de IV,5,1 é a complementaria da que teñen as leis do bloque anterior: aínda que o obxeto da lei sexa a de salvagardar o dereito á herdanza dos descendentes (De non exherendandis filiis; et quod iudicium ferant parentes de facultatibus suis) e limitar a mellora de calquera deles a só un tercio, sen embargo non vai ser por ningunha destas razóns que se acuda a esta lei; pola contra, é o quinto de libre disposición ${ }^{47}$, tal e como aí se recolle, o que explica o interese por IV,5,1. A complementaridade á que me refiro enténdese como o interese da Igrexa por abranguer tódalas posibilidades de doación baixo a cobertura legal dos preceptos da Lex:

\footnotetext{
${ }^{47}$ «Sane si filios sive nepotes habentes ecclesiis vel libertis aut quibus elegerint de facultate sua largiendi volumtatem habuerint, de quintam tantum partem iudicandi potestas illis indubitata manebit», di a lei; «Et dedimus in ipso loco sancto de sua hereditate sua quinta sicut lex gotica disnunciat et canonica censura confirmat...», lemos na doación que Iusta fai ó mosteiro de Ardón en 1009, ou «...nos facimus sicut oportet fieri ut omnes cuncti quintam reddant ecclesie de omni divicia sua proinde damus ista villa...», en Oviedo en 1058.
} 
aqueles que non teñen descendencia doan escudándose en IV,2,20, e os que (mala sorte) si a teñen, alegan IV,5,1 para doar unha nunca menospreciable quinta parte.

$\mathbf{I V}, \mathbf{5 , 6}$ e as leis que forman $\mathbf{V}, \mathbf{1}^{48}$ artéllanse como aparato defensivo desas propiedades da Igrexa: a primeira delas actúa excluíndoas do período de trinta anos que, según X,2,3 e X,2,5, elimina calquera posibilidade de reiniciar un pleito ou esixir unha propiedade; é dicir, que ninguén pretenda conservar un ben usurpado á Igrexa, coa excusa de telo posuído durante máis de trinta anos, porque o que é dado á Igrexa sempre a ela lle pertence. En principio é unha lei feita para evitar a tendencia dos bispos a enaxenar os recursos da igrexa catedral, pero en tódolos casos seleccionados para este traballo esta lei é usada contra laicos. En canto ó primeiro título do libro $\mathrm{V}$, tódalas leis inciden tamén nesa condición non enaxenable dos bens eclesiásticos, que é o principal interese que se respira detrás de todas as alusións coas que nos atopamos: «sicut constitutum est in lege gotica, quod de rebus ecclesie nemo emere vel vendere vel minuere audeat», é o argumento que fai que en 1028 Oveco Orbitaz devolva ó mosteiro de Sahagún as terras que uns frades lle venderan ó seu sogro. Sen embargo, mentres IV,5,6 se emprega principalmente en pleitos (como os de Guimarães de 1050 e 1053, ou o de Sahagún de 1067), estas outras leis tenden a formar parte de documentos de doación, concordando máis co sentido global deste libro V (De transactionibus), e tendendo máis, pois, cara ese nivel diplomático do uso da Lex.

\footnotetext{
${ }^{48}$ A afinidade entre IV,5,6 e as leis de V,1 leva ós editores do Fuero Juzgo da Real Academia Española a editar a primeira como V,1,5, a pesares de que, como eles xa din, non é esta a colocación que lle adxudican tódolos códices castellanos; tamén pode ser esta relación natural a que leve, en 1050 en Guimarães, ó xuíz Pelagio Sagatiz a citala como $\mathrm{V}, 1,1$, o que tampouco sería tan sorprendente se temos en conta que sería desplazala só un posto: do final do libro IV ó principio do $\mathrm{V}$, xa que polo medio só hai unha lei (a IV,5,7 sobre servos da Igrexa, que os anteriores editores colocan como V,1,6). Desta lectura «errónea» creo que non se pode culpar ó códice manexado, xa que só tres anos despois, nun pleito que envolve ó mesmo mosteiro de Guimarães, e no que o tal Pelagio Sagatiz actúa agora como assertor do mosteiro, a cita desta lei faise «correctamente» como IV,5,6, agora da man do xuíz Didaco Tructesindiz, que xa aparecía citando a Lex en Coimbra no 1040. ¿Este xuíz lía mellor? ¿Ou é que quizais se usou outro exemplar? Sería raro, aínda que tamén hai que ter en conta que agora o pleito é pola posesión do mosteiro de Lalín, o cal contaba cun exemplar do Liber dende que en 1019 llo doara a condesa Adosinda Gudesteiz (vid. n. 11)
}

"CUADERNOS DE ESTUDIOS GALLEGOS", Tomo XLIV, Fascículo 109, Santiago 1997. 
Pero antes de rematar co libro IV, sería interesante chamar a atención sobre un dato: tal e como salienta Y. García, dende pronto se estableceu certa relación, mesmo certa unidade, entre o Liber e as dúas primeiras lexislacións que se fixeron, con carácter global, para todo o reino: o Fuero de León de Alfonso V, e os decretos de Coyanza de Fernando I, ata o punto de chegar a organizarse os tres nun único códice, quizais xa antes de finalizar o século $\mathrm{XI}^{49}$, e do que temos como testemuña alomenos tres exemplares. Non se trata aquí agora de discutir as razóns que levaron a isto e ó maior ou menor éxito que poido ter unha compilación legal que se pretendía, está claro, total e xeral para todo o reino, senón simplemente resaltar a importancia que tales lexislacións reais, e en especial os decretos de Coyanza, poideron ter como impulsores do coñecemento do Liber, que non deixaba de ser o punto de referencia sobre o que estes dous reis estaban a lexislar. Este comentario ven provocado pola difusión de IV,5,6, a lei que acabamos de comentar, xa que é unha das tres leis góticas ás que Coyanza fai mención explícita (xunto con II,4,6 e IX,3,1): «Nono quoque titulo precipimus ut tricenium non includat ecclesiasticas veritates sed unaqueque ecclesia, sicut canones precipiunt et sicut lex gotica mandat, omni tempore suas veritates recuperet et possideat». $\mathrm{O}$ chamativo é que tódalas alusións ${ }^{50}$ que se fan a IV,5,6 son posteriores a Coyanza. ¿Poido ter influído esta disposición real na difusión desa lei en concreto? É posible que si, e ademais de varias formas: a súa inclusión entre os decretos supón certa actualidade do problema, ó tempo que lembra a solución legal máis axeitada, de forma que non había de faltar quen prestase moita atención; por outra banda, a edición conxunta das tres «lexislacións» reforzaba a posibilidade dunha consulta múltiple e facilitaba a tarefa de atopar a disposición concreta, así como unha relativa familiaridade con ela. Pero tamén hai que ter en conta que dous dos documentos que a citan (os de Oviedo de 1075 e 1083, dous pleitos pola posesión do mosteiro de San Salvador de Taule) están recollidos no Liber Testamentorum do bispo Pelayo de Oviedo, que é tamén unha das fontes pola que se nos transmiten os decretos de Coyanza, de xeito que é posible

${ }^{49}$ Para a orixe e a data desta particular ordinatio, compre ver Y. GARCÍA, op. cit., pp. 352-358.

${ }^{50}$ Todas ou case todas, dependendo de se a data para Coyanza é 1050 ou 1055, como se discute.

"CUADERNOS DE ESTUdIOS GALLEGOS", Tomo XLIV, Fascículo 109, Santiago 1997. 
pensar en certa «adaptación» dos ditos documentos á luz dos decretos de Fernando I, que se transcriben uns trinta folios antes. ${ }^{51}$

Pero o libro V, e deixando xa aparte o título primeiro, aínda nos ofrece outra mostra das posibilidades de explotación do Liber na documentación leonesa. $\mathrm{O}$ interese e a finalidade deste uso, sen embargo, vai seguir na mesma liña que vimos vendo ata o de agora: dar cobertura legal ós actos de doación, venda, intercambio..., lóxico no libro De transactionibus. Neste caso, o que se salientan son as dúas condicións esenciais que dan validez a calquera cambio dunha propiedade: por un lado, que sexa unha transacción feita de xeito voluntario, sen coacción, «non fuerit per vim et metum extorta» ${ }^{52}$, tal e como remarcan, sobre todo, $\mathbf{V , 2 , 1}$ e $\mathbf{V}, \mathbf{4 , 1}$; e, por outro lado, que o rexistro escrito desta doación ou venta ten unha validez total, igual que unha transacción ante testemuñas, condicións estas nas que inciden $\mathbf{V , 2 , 6}$ e $\mathbf{V}, \mathbf{4 , 3}$. Con razón imos topar só cartas de venta ou doación, e non pleitos ${ }^{53}$, porque de novo estamos ante un uso diplomático

${ }^{51}$ De feito, a orixe que GARCÍA GALLO propón para esa edición conxunta de Liber, Fuero de León e Coyanza, é o taller de Pelayo de Oviedo (vid. Y. GARCÍA, op. cit., pp. 353-354). Tamén hai que chamar a atención sobre eses dous documentos, de 1075 e 1083 : os dous recollen de forma case idéntica o mesmo pleito, pero con protagonistas distintos, e citando no de 1083 un par de leis máis, entre elas a lei sobre concubinato que aparece en (L). Un dos que aparece como xuíz no pleito de 1075, Rodericum Didaz castellanum, é o que se enfronta ó bispo ovetense no pleito de 1083, mentres que neste último actúa como xuíz Citi Ansemondiz ex urbe Lucensi, que no de 1075 fai de assertor dos irmáns Tritoniz, que sos os que nesa ocasión se enfrontan á se ovetense. Resultan, canto menos, documentos moi confusos, coas referencias dos títulos e sentencias en blanco, e que nos poñen ademais sobre aviso do cambio de perspectiva que supón o traslado do diploma orixinal a un cartulario, o que pode provocar tanto alteración interesadas das citas, como simples erros de copia, porque quizais o monxe que estea copiando no século XIII unha cita da Lex non saiba moi ben que é o que esta reproducindo, ou mesmo acorte unha cita que non considera importante.

${ }^{52}$ «in lex coto(...) de in libro $V^{o}$ et titulo VIII $^{o}$ qui dice -ece quomodo valent venditio sicut ed entio- non per metum de nulis homo neque per ebrietas vinum neque perturbatio cordis sed corde directo integro consilio tempus pacificus et mentes consideratas.», dise en Guimarães en 1099, engadindo algún outro motivo limitador das capacidades do doante.

${ }^{53}$ Agás, outra vez, o pleito de León de 952, onde se fai unha cita bastante completa de V,2,6, aínda que nesta ocasión é para aproveitar unha cláusula concreta da lei que non se usa no resto dos casos: refírome á posibilidade de recuperar unha posesión deixada en usufructo, aínda que detrás houbera unha promesa de testamento, o cal, tal e como argúen os monxes de Abellar, sempre se pode cambiar mentres o testador viva; e así, de feito, o fixeran o tal Arbario e a súa muller dando os seus bens a este mosteiro, malia as reclamacións de Velasco Hanniz, que antes os disfrutara en usufructo.

"CUADERNOS DE ESTUDIOS GALLEGOS", Tomo XLIV, Fascículo 109, Santiago 1997. 
da lei; a cita se incorpora como cláusula de garantía do negocio que se rexistra, e, xa que logo, cunha forte tendencia a fixarse formulisticamente. E nesta tendencia, non sempre vai ser doado identificar a lei exacta que se tenta reproducir; a mestura de termos e conceptos, mantendo sempre algunha desas dúas ideas centrais (voluntariedade do acto e rexistro escrito ou público), amosa que na meirande parte dos casos non se trata dunha consulta do códice, o que, por outra banda, non deixa de ser normal se estamos a falar deste uso diplomático. De aí que no apartado do libro V, que se recolle na táboa II, os documentos van colocados xunto á lei que citan ou que serve de base para a particular cita que neles se concrete. En todo caso, si se pode distinguir tres expresións básicas:

-a intitulatio de V,2,6: «De rebus traditis vel per scriptura donatis», ou as primeiras liñas da lei: «Res donate, si in presenti tradite sunt, nullo modo repetantur a donatore», ou V,4,3 «Venditio per scripturam facta plenam habeat firmitatem», todas elas para salientar o valor do rexistro escrito ou do acto feito en público.

-«Donatio, que per vim et metum fuerit extorta, nullam habeat firmitatem», como estipula $\mathrm{V}, 2,1$, para amosar que se trata dụn acto voluntario.

-e a expresión «Valeat donatio sicut et venditio», máis ou menos baseada en $\mathrm{V}, 4,1$, coa que se pretende dar a todos estes actos de transmisión de propiedades a mesma forza, en especial á doación.

Estas son as formas que se poden rastrexar botando un vistazo ós exemplos que se recollen na táboa II, e que outra vez nos vai a amosar a particular fecundidade do territorio portugués nestas fórmulas baseadas no Liber. Pero non paga a pena seguir insistindo nesta utilización da Lex.

Chegados ata este punto, e sen térmonos atopado con grandes sorpresas, vemos como, de repente, o Liber se nos acaba: parece como se no reino de León ${ }^{54}$ só se manexasen exemplares truncados á altura do libro $\mathrm{V}$, porque máis aló so temos catro ou cinco exemplos puntais, e algún deles mesmo moi dubidosos ${ }^{55}$. ¿Como se entende isto? Que o libro I, De

\footnotetext{
${ }^{54} \mathrm{E}$ non só no reino de León: se se atende o reconto que ZIMMERMANN fai para Cataluña, os resultados son moi parellos, se excluímos o feito de que o libro IV ten moi pouca presencia: maioría de citas de V e II, moitas menos de III, ningunha de I, IX nin XI, e casos puntuais de VI, VII e VIII (op. cit., pp. 251-254).

${ }^{55}$ Refírome os xa comentados de Oviedo de 1075 e 1083.
}

"CUADERNOS DE ESTUDIOS GALLEGOS", Tomo XLIV, Fascículo 109, Santiago 1997. 
instrumentis legalibus, non teña cabida nun uso cotiá do Liber é obvio, como xa vimos; e tamén se pode comprender que o XI, polo concreto e moi particular do seu contido, tampouco se usara de forma frecuente, xa que se centraba sobre casos de actuación médica ${ }^{56}$, sobre profanacións de tumbas e sobre mercaderes de ultramar (De egrotis et mortuis adque transmarinis negotiaribus). E podemos aceptar tamén, con algunhas reservas, que a maior mobilidade do campesinado, nun momento de máxima actividade repoboadora, limitaría o interese e a actualidade dun libro que, como o IX, lexisla sobre servos fuxidos ${ }^{57}$ (De fugitivis et refugentibus). Do libro X, De divisionibus et annorum temporibus adque limitibus, (do que só temos os documentos ovetenses mencionados que citan X,2,3) non se recurre para nada ó título sobre os conflictos de lindes entre terras, que nunca deixou de ser un problema candente; pero polo menos son frecuentes os litixios de terras que se resolven polo sistema que se recolle en X,3,3: un grupo de homes nomeados polo xuíz van seguindo as lindes na busca dos fitos ou señais que marquen os términos antigos de división entre propiedades.

E aínda entra dentro do normal que toda a política antixudea dos reis visigodos, tal e como se define minuciosamente no libro XII, De removendis pressuris et omnium hereticorum sectis extinctis, tampouco teña a actualidade suficiente (polo de agora) como para que se bote man del.

¿Pero como explicar o resto? Do libro III, De ordine coniugali, cabe esperar algo máis que a media ducia de casos, case todos pleitos, que se ven na táboa: un adulterio no León de 994, un monxe que, dinnos en 1006, «comiscuit se cum muliere, filia perdiccionis», un rapto en 1022, un rebelde que non quere casar con quen o rei ordea en $1059 \ldots$, pouco máis temos para un mundo de problemas como é o da temática conxugal. Pero maior é aínda a decepción que deperta o (non) uso dos libros VI (De sceleribus et tormentis), VII (De furtis et fallaciis) e VIII (De inlatis violentiis et damnis): ¿non hai pleitos por homicidio, ou por roubo, ou por

${ }^{56}$ Un dos documentos incluídos no apéndice por outra razón, poido ter recurrido a unha lei deste libro (XI,1,5), xa que recolle o pago ó médico que cura ó seu enfermo dunha posible cegueira (se cadra de cataratas). É o de Braga de 1077.

${ }^{57} \mathrm{~A}$ única referencia a IX que temos é un dos decretos de Coyanza, no que se lembra que o espacio da igrexa é lugar de asilo para quen nela se refuxie (IX,3,1).

"CUADERNOS DE ESTUDIOS GALLEGOS", Tomo XLIV, Fascículo 109, Santiago 1997. 
aborto, ou por falsificación, ou por destrozo de colleitas,...? ¿ ¿ou si os había, pero non se citaba a Lex? Porque isto é o que parece deducirse do material co que contamos: unha alusión a un pleito por homicidio, en 1020 en León, no que se alega unha pequena parte de VI,5,12, e dous pleitos por roubo de gando, en Otero de las Dueñas 1018 e 1019, resoltos seguramente polo mesmo xuíz coa mesma lei (VIII,1,6) e, sobre todo, beneficiando ó mesmo conde. Cabía esperar algo máis.

Se cadra a explicación veña por outro lado: que non teñamos rexistrado o uso do Liber para casos de roubo, de homicidio, de danos nas colleitas, non quere dicir que non foran leis de feito consultadas nos procesos correspondientes e mesmo rexistradas nunhas posibles actas xudiciais (da existencia das cales Prieto Morera, por exemplo, está convencido) $)^{58}$; pero os documentos que hoxe posuímos son elaborados sobre unha selección interesada daquelas (é dicir, son eses plácitos de aseguramento dos que fala este autor, ou máis ben aínda, os documentos que se elaboran sobre eses plácitos), pero só no caso dos procesos que afectan dalgun xeito a unha propiedade inmoble; e como cabe pensar que un proceso por roubo (enténdase, dun ben moble), ou por homicidio, e moito menos por consultar a un médico, non vai garantir a propiedade de ningún ben inmoble, non xenera ningún título de propiedade que valla a pena conservar co rigor e co coidado co que as institucións eclesiásticas elaboraron os seu cartularios $;{ }^{59}$ a non ser que ese proceso se acabe resolvendo coa entrega dalgunha terra e, xa que logo, teña máis sorte na súa conservación (por exemplo, os que citan VIII, 1,6 en 1018 e 1019).

Todo isto fai que a nosa impresión sobre a vixencia do Liber no reino de León estea deformada por esta transmisión selectiva, e que o peso do uso diplomático, e dun uso xurídico un tanto limitado, se nos impoñan sobre

\footnotetext{
${ }^{58}$ «Sobre a base de non se teren conservado arquivos xudiciais (partimos da hipótese da súa existencia) o lóxico é que os diplomas conservados sexan copias das devanditas sentencias...», PRIETO MORERA, op. cit. p. 389.

${ }^{59}$ «...as partes vencedoras [dos pleitos sobre terras] tiñan interese en posuír estas escrituras e preservalas: supuñan unha seguridade adicional ó título e, como se verá, algunhas servían especialmente para prever a resurrección das reclamacións derrotadas. [...] Outras formas de rexistro legal neste período, especialmente o relativo o que preferiríamos clasificar como criminal máis que como casos civís, en xeral non sobreviviron porque había pouca necesidade ou incentivos para preservalos.» $\mathrm{R}$. COLLINS, "Sicut lex Gothorum continet: law and charters...", pp. 490-491.
}

"CUADERNOS DE ESTUDIOS GALLEGOS", Tomo XLIV, Fascículo 109, Santiago 1997. 
unha utilización máis rica e diversa. ¿Usábase o Liber fóra destes casos?, é dicir, ¿servía o Liber para algo máis que para dar solidez a un patrimonio, sobre todo eclesiástico, construído a base de doacións? Estou convencido de que si, pero non é doado confirmar esta impresión ó traverso da documentación chegada ata nos.

Sen embargo, existe outra vía de achegamento que nos pode proporcionar indicios de que o coñecemento (e case con seguridade tamén o uso) do Liber ía algo máis aló. A cuestión é desplazar a nosa mirada, deixar de preguntarnos qué é o que se cita e pasar a buscar a quén o fai e cómo. A posibilidade de atoparnos con xuíces capaces, coñecedores da Lex, habituados a manexar o Liber, quizais nin sequera eclesiásticos, ampliaríanos a perspectiva e daría base para defendermos, con máis credibilidade, a forza da pervivencia desta herdanza visigoda. Ou alomenos é o que se pretende no seguinte apartado.

\section{IUDICES QUI LEX GOTORUM SOLENT COMPROBARE}

Non se trata aquí de facer un estudio da figura do xuíz nestes séculos (as súas funcións, a súa preparación, a súa procedencia social...), senón só analisar, ó traverso dos documentos máis locuaces ${ }^{60}$, cal era a particular relación que estes personaxes mantiñan co código legal visigodo. A descripción do manexo e do coñecemento do Liber por parte de individuos concretos é o aspecto máis tanxible da pervivencia da Lex, e na medida en que estas habilidades nos permitan facernos unha idea do papel do códice legal durante o proceso, entón poderemos superar un pouco a visión

\footnotetext{
${ }^{60}$ Para isto, os que ofrecen unha máis aproveitable información son os de Lugo 922, León 952, Samos 985, Celanova 987, Sobrado 992, Guimarães 999, Celanova 1005, Coimbra 1004, Coimbra 1013, Guimarães 1014, Otero de las Dueñas 1018 e 1019, Lugo 1019, León 1021, Otero de las Dueñas 1022, Coimbra 1025, Braga 1025, Celanova 1025 e 1030 , Guimarães 1038, Coimbra 1040, Pendorada 1047, Oviedo 1050, Guimarães 1050 e 1053, Celanova 1054, Pedroso 1060, Braga 1062, Sahagún 1067, Guimarães 1072, Braga 1073, Oviedo 1075, Coimbra 1075, León 1076, Oviedo 1083, Braga 1089, Arauca 1091 e Moreira 1121. Son case todos eles documentos "procesais" nos que o Liber está claramente usado e nos que hai algún tipo de indicación sobre quen é o responsable dese uso. Do doc. de 1014, pódese ver a reconstrucción do proceso nas súas distintas fases en PRIETO MORERA, op. cit. 479-481.
}

"CUADERNOS DE ESTUDIOS GALLEGOS", Tomo XLIV, Fascículo 109, Santiago 1997. 
monofocal á que nos somete a transmisión dos textos e plantexarnos a posibilidade dunha administración de xusticia máis complexa e completa. «Nas dúas áreas [refírese a Cataluña e ó reino de León] os tribunais estaban controlados por un grupo de xuices, ó redor da media ducia, que parecen ter sido profesionais, como as súas frecuentes citas do Forum Iudicum indicarían. Como e onde recibírían a súa formación non se sabe. Eran eles, e non os prestixiosos presidentes, os que facían as preguntas no tribunal e emitían as instruccións. ${ }^{61}{ }_{»}$

Esta idea da figura do xuíz como «profesional» da xustiza faise moi atractiva, e máis se esa «profesionalidade» se vencella, dalgún xeito, ó uso do Liber. Iso é o que parecen facer toda unha serie de expresións recollidas na documentación que manexamos, e que nos informan, de xeito explícito, sobre a existencia de individuos que coñecen o Liber e que se adican ó seu estudio e á súa aplicación. E tendo estas mencións tan claras, disminúe o risco que supuña interpretar as actúacións doutros xuíces, con respecto ó libro, como actuacións competentes e formadas, e permite, ó mesmo tempo, facer máis verosímil a idea de que existía unha preparación suficientemente sólida como para empregar o código visigótico en máis supostos dos que realmente coñecemos. En todo caso, a relación de «profesionais do Liber « é por si mesma significativa:

Lugo 922 - «...iudices qui lex gotica docent Elcino Quendulfiz, Ioacinus Cartemiriz...»

Celanova 1005 - «...ordinaverunt iudices constituti, discernisserunt inter eos veritas sicut lex gotica docet. Fuerunt ipsi iudices pronominati, Fredenando Sandiz, Froila Eroptiz, Pelagius Arnaldiz. Et dederunt inter eos libris...»

${ }^{61}$ R. COLLINS, "Sicut lex Gothorum continet: law and charters...", p. 506. Este mesmo autor, pero en "Literacy and the laity in early mediaeval Spain", ratifica esa "profesionalidadẹ" decindo: «Estes [os xuíces profesionais] non so caracterizarían a lista de xurados que se sentan nas vistas senon que tamén poden ser atopados usando iudex como un título ou marca do seu estatus en documentos privados nos que participan sen ter nada que ver coa execución das súas responsabilidades xudiciais.» p. 129. Este é o caso do xa coñecido xuíz do pleito de Braga de 1025, que aparece suscribindo como Adeita Furtuniz iudex a doación de 1013 (vid. n. 64), na que aparece a cita máis completa de IV,2,20, a todas luces citada cun exemplar do Liber diante.

"CUADERNOS DE ESTUDIOS GALLEGOS", Tomo XLIV, Fascículo 109, Santiago 1997. 
Guimarães 1014 - «...suos iudices que legem docebant id sunt Froila Erotiz, Honoricus Zaleimaz, Vermudo Todemiriz, Menendus Gaviniz, Egas Menendiz, Ranemiro Menendiz...»

León 1021 - «...et post partem rex et potestas qui speculatorem legem dederit...»

Guimarães 1038 - «...Oveco Ennegoz, Roderico Tractemiriz, Ermias Flomarigoz que lex docent...»

Pendorada 1047 - «...ante iudices qui lex gutorum solent conprobare pernominatus Gomize aba et frater Raupario et Arias Onoquiz et Zidi Minoriz.»

Celanova 1054- - «latores legum nominati Pelagio Petriz portugalensis, Daut Domniniz et Gudestedo Froilaz limianense,...» Pedroso 1060 - «...per omines sapetores et doctores legis dicentes iudices et magistratus ut non valeat testum...»

Braga 1073 - «Et iudices qui ibi erant Gundisalvus Munniz, Gundesindus Moniz, Rodericus Cidiz qui Legem Gotorum solent comprobare...»

Coimbra 1075 - «...iudex qui lex gotorum solent comprobare Menendus Sesequiriz et Fronerigus Teoderiz...»

León 1076 - «...et post partem rex e potestas qui speculatorem legem dederit...»

Braga 1089 - «...Gotierre Pelaiz qui Lex Gotorum solet comprobare quod vidit renuntiavit...»

Moreira 1121 - «Coniuro vos iudices que lex Gotorum solent comprobare...»

Por un lado, verbos como docent, ${ }^{62}$ comprobare, ou formas como

\footnotetext{
${ }^{62}$ «Pero nada proba que este doceo sea aplicable á docencia; pode derivar a súas connotacións do papel tutelar dos xuíces, ou mesmo do acto físico de «amosar», de saber «sinalar» a sentencia da Lex axeitada ó caso». Y. GARCÍA, op. cit., pp. 415-416. A desilusión da autora é non poder atopar aquí algunha proba dunha adicación do Liber ó ensino, á aprendizaxe de xuíces e notarios, como si se sabe para Cataluña. Quizais non haxa que pensar nunha formación institucionalizada; R. COLLINS di que «para os xuíces laicos é bastante prudente pensar que non existía nada parecido a unha formación profesional. No mellor dos casos, eles poderían ben ter aprendido a súa profesión no seu exercicio ou por instrucción persoal por parte doutros exercedores», en «Literacy and the laity in early mediaeval Spain», p. 131, o que non ten porque supoñer que de feito non haxa quen saliente polo seu coñecemento do Liber fronte a xuíces menos formados; e se cadra sexa a dispoñibilidade dun exemplar a que peermite tal preparación.
}

"CUADERNOS DE ESTUDIOS GALLEGOS", Tomo XLIV, Fascículo 109, Santiago 1997. 
speculatorem, ou latores legum, indícannos a actuación concreta destes personaxes coa Lex: buscar a lei correspondiente e mostrala, levar consigo a Lex e ser quen de manexala e consultala. Pero por outra banda, algunha especificación nos dá a entender que esta habilidade os caracterizaba de forma permanente: qui solent comprobare, ou a denominación sapetores et doctores legis ${ }^{63}$, conferíndolles unha posición que quizais non compartiran tódolos xuíces.

En calquera caso, está claro que había unha utilización física do códice durante os procesos, e que aínda sen ser denominados como sapetores legis, moitos outros xuíces se nos presentan consultando un exemplar (non sei se propio ou pertencente a algunha institución eclesiástica $)^{64}$. Son frecuentes as expresións verbais que indican que se «vai ó libro» para facer a consulta ${ }^{65}:$ «...ut perquirerent recta veritate per sententiis legum, et ante tractarent super hoc negotium invenerunt in libro II...», se di no documento de Celanova dos latores legum, ou «Invenimus in libro $I I I^{o} \ldots \gg$ di o xuíz do caso de rapto de Otero de las Dueñas de 1022, ou «...et invenerunt in Iudicum libro segundo...», en Sahagún en 1067 referíndose ó xuíz leonés Petro Gonzalviz, ou «...sic invenit ipse iudice in liber quintus...», como vemos que fai en Guimarães en 1050 o xuíz Pelagio Sagatiz.

Ademais, a propia forma de citar é indicativa de se se fai cun Liber diante ou de memoria: non me refiro xa a citas que, pola súa extensión e rigurosidade con respecto á Lex, non espertan dúbidas de como foron

\footnotetext{
${ }^{63}$ Quizais teña este mesmo sentido a expresión «...omnia notuimus quod de octores [por doctores] intellegunt et veritate perexquirant qui fuit in altercatio in presentia episcopus domnus Petrus cathedre Bracarensis et abba Suario Pelaiz ut aliquis homo...», citada en Braga no 1072. ¿Será este Suario Pelaiz a mesma persoa que o Gutierre Pelaiz, que se cita en Braga en 1083 e que se recolle na lista anterior? Se fora así, plantexaríasenos o problema de que a condición eclesiástica pode aparecer expresada ou non.

${ }^{64}$ «Referencias documentais deixan claro que moitos dos principais mosteiros $e$ igrexas episcopais posuían copias do código. Moitos dos seus abades actúan como xuíces en casos que aparentemente non atinxen ás súas casa.» R. COLLINS, op. cit., p. 131. ¿Non pode ser este o caso, por exemplo, dese Gomize aba e frater Raupario de Pendorada 1047, ou o Petrus abba e Astrulfus confessus, do pleito de Sobrado de 992?

${ }^{65}$ Expresións que son o complemento lóxico daquelas outras polas que os litigantes aceptan someterse á lei: «proclamaverunt se uterque ambo ad librum et qualem ex his liber mandasset stabilire...», ou «...et fuimus ad librum, et iudicavit...'», e onde se ve esa identificación Lex $=$ Liber.
}

"CUADERNOS DE ESTUDIOS GALLEGOS", Tomo XLIV, Fascículo 109, Santiago 1997. 
feitas ${ }^{66}$, senón a outros rasgos indirectos que demostran que se «estaba a ler»: é por exemplo o caso de Braga de 1025, xa varias veces comentado pola súa rigurosidade, onde o xuíz Furtuniz cando cita II,4,5 fai unha indicación para que nos decatemos de que a cita está na súa case totalidade agás unha pequena frase, excluída pola razón que for (indica onde empeza a copiar coa expresión "ibi dicit...et ibi dicit"); a forma «ubi dicit» é moi frecuente como iniciador da cita.

Neste sentido, tamén se poden incluír aquelas alusións nas que se selecciona simplemente a frase literal necesaria para resolver o caso, sen transcribir todo o aparato que adoita envolver moitas das sentencias visigodas, e excluíndo ó mesmo tempo aquelas estipulacións que non veñen a conto; este uso «intelixente» da cita é o que se observa, por exemplo, cando Petro Gonzalviz, no pleito de 1067, se remite a II,4,3 pero só para transcribir «Quia in duobus testibus quos prisca legum sanxit auctoritas debet firmare iudicius»; ou cando o xuíz que resolve o pleito por homicidio ó que se alude en León en 1020, recorre a ampla lei VI,5,12 pero só para recoller a cláusula na que se castiga o homicidio feito por varios en conspiración.

E se este uso nos desvela unha lectura competente, noutras ocasións é o fenómeno contrario o que acredita a existencia dun exemplar; trátase das citas rexistradas de forma pouco coidadosa, como da que é responsable Didaco Tructesindiz en Guimarães en 1053: identifícase máis ou menos ben a lei, escrébese o encabezamento e, de seguido, coménzase co texto que se corta de xeito abrupto e sen sentido ás poucas palabras ("...et in liber $V^{o}$ sentencia II ${ }^{a}$ ubi dicit De conservatione et readintegratione ecclesiatice rei consultissima regni nostri credimus providere remedia."). ${ }^{67}$ Son precisamente erros de lectura ou de copia, que non

${ }^{66}$ Documentos como os de León 952, Guimarães 1013, Otero de las Dueñas 1018, León 1019, Otero de las Dueñas 1020 e 1022, Celanova 1054, Oviedo 1075 e 1083 (con reservas),...

${ }^{67} \mathrm{E}$ malia non se lucir, faino algo mellor que o seu compañeiro Pelagio Sagatiz, que cita tres anos antes a mesma lei e nin sequera a identifica ben (vid. n. 48). De todos xeitos, o que nos interesa é salientar que dispoñen dun exemplar e que o están a usar no pleito. Salientar isto é importante, sobre todo para Portugal, para o que non se constatan restos nin doacións do Liber; ¿pero isto impide pensar que o mosteiro de Guimarães posuía un exemplar?, creo que non, ¿ou é tan descabellado pensalo se temos ademais en conta que o mosteiro de Celanova, co que o de Guimaraes mantivo estreitas relacións dende a súa fundación, posuía un dende o 938, cando que llo doara Ilduara Eriz?; e o mesmo sucedía, como xa se dixo, co mosteiro de Lalín, co que tamén estaba relacionado.

"CUADERNOS DE ESTUDIOS GALLEGOS", Tomo XLIV, Fascículo 109, Santiago 1997. 
poden ser resultado dunha fixación memorística (como si o poden ser todas aquelas fórmulas que se van modificando pero mantendo a idea central da lei) senon dun uso palpable do libro. Pero cabe facer dúas matizacións: por un lado hai que ter en conta a posibilidade de que estes erros sexan posteriores (copia do diploma no cartulario) e non atribuibles ó xuíz, o que non afectaría ás conclusións que destes exemplos se sacan (é dicir, que foron feitas cun libro diante); e por outro lado, que si esta era a forma na que a cita quedaba rexistrada no documento resultante do pleito, entón é posible pensar que o valor sancionador da lei gótica podía apoiarse, ás veces, na maxestuosidade de citas inintelixibles, comprensibles na súa totalidade só para estes sapetores legis e amenazantes para todo aquel que, alleo a este mundo, tentase ir en contra das decisións tomadas e así refrendadas; que a cita quedara un tanto inintelixible non era maior problema, unha vez que a lei tiña a garantía da identificación da súa orixe (libro, título, sentencia), localizable pois por calquera coñecedor da Lex.

$\mathrm{O}$ certo é que, e deixando xa aparte a aqueles mencionados na lista anterior e os outros xuíces que xa fumos nomeando, os testimonios de xuíces actuando cun Liber debaixo do brazo son abundantes: tiñan un libro (e o lían) Bera Zanoniz e Fagildus confessus cando en 999 tiveron que resolver un pleito «et ordinaverunt per librum iudicum ut traucisset Vimara Muniuz...». Tamén dispuña doutro o Adefonso iudice que sentencia nos pleitos por roubo de gando de 1018 e 1019. Pelagio Asuriz e Martino Lilaci lle sacan rendimento ó seu exemplar, en León en 1022, igual que Petro Gonzalviz, en León en 1067 ou Arias Didaz en Braga en 1062. E aínda habería que engadir os responsables das citas explícitas que aparecen en documentos que, pola razón que for, non inclúen o nome dos xuíces (por-exemplo, doacións que fan alusión a un pleito anterior onde se empregou a cita), así como tamén a aqueles que aparecen nos pleitos sen citar ningunha lei e limitando o seu coñecemento do Liber a dirixir o proceso dentro das normas (atender ós alegatos, examinar as probas, organizar as testemuñas e dictar a sentencia) e que quizais tamén poideran botar man dalgún exemplar, de ser necesario.

Unha boa base humana para soster a aplicación dun código legal complexo, completo e total; limitar o seu uso ás facetas e campos que os documentos preservaron semella desperdiciar tanto a riqueza da Lex Gotica como a preparación dos latores legum. É por iso que afirmar que a táboa II é un pálido reflexo da realidade convértese en convencimento de sentido común.

"CUADERNOS DE ESTUdIOS GALLEGOS", Tomo XLIV, Fascículo 109, Santiago 1997. 


\section{CONCLUSIÓNS}

¿Que conclusións podemos tirar de todo isto? En primeiro lugar, creo que non podemos deixar de decatarnos de que o Liber, como código e como códice, era manexado e consultado ${ }^{68}$, mesmo naquelas zonas para as que hoxe non dispoñemos nin de exemplares nin de testimonios directos dos mesmos; se cadra a relación de leis concretas que se poideron identificar sexan unha moi pálida e pouco equilibrada representación do máis de medio millar de estipulacións que constitúen o artellado código legal visigodo, pero razóns se teñen exposto para tentar xustificar esta «selección» da información chegada ata nos. Tampouco se pode deixar pasar por alto o panorama que a documentación nos esboza para o coñecedor do Liber: a preparación (¿onde?, ¿con que medios?, ¿con que fin?) destes personaxes, en gran parte laicos, que puñan a súa pericia a servicio do tribunal, é unha cuestión clave para desentrañar o funcionamento e as posibilidades da administración da xusticia; un estudo máis pormenorizado destes «xuíces profesionais» -e tamén doutra figura constante nos procesos, como é o saión- iluminaría de forma extraordinaria o cadro xurídico, porque se ben podemos estar tentados a vencellar o coñecemento profundo pero puntual do código coa posesión afortunada dun códice, non podemos esquecer o carácter laíco de moitos deses sapetores legis e, xa que logo, non podemos contentarnos con interpretar ese coñecemento do Liber como o erudito interés dalgún monxe ou eclesiástico pola obra que se tería conservado na biblioteca do seu mosteiro ou da súa igrexa catedral, e que permitiría lexitimar os actos xurídicos cos que a institución estaba enriquecendo o

\footnotetext{
${ }^{68}$ «Esta deducción é reforzada pola evidencia dos mesmos manuscritos sobrevivintes do Forum Iudicum. Case todos poden ser vistos como códices 'traballados'. Eran xeralmente bastante pequenos, non necesariamente escritos no mellor pergamino, cunha moi limitada ornamentación, que non limitaba de ningunha forma a lexibilidade do texto. O elemento ornamental, que amosa signos de estandarización e que podería derivar de prototipos visigóticos, parece querer realzar a comodidade de acceso ós contidos do libro.», R. COLLINS "Literacy and the laity in early mediaeval Spain", p. 130. de todos modos, isto é matizable: algún manuscrito destes en principio moi manexables, mesmo con abundantes glosas, ten o texto máis complexo e inintelixible de todos, mentres que tampouco se pode descartar a forza propagandística que nun tribunal podía causar un grande e ornamentado códice como reflexo do peso da autoridade (estas reflexións débollas a YOLANDA GARCÍA).
}

"CUADERNOS DE ESTUDIOS GALLEGOS", Tomo XLIV, Fascículo 109, Santiago 1997. 
seu patrimonio; pola contra, o panorama semella máis complexo, porque hai que presumir unha formación xurídica laica, máis clara no XI ca no X, na que o Liber tiña un papel central, como texto de autoridade e como código.

O Liber, pois, usábase; quizais non se usara sempre, en tódolos pleitos, porque quizais tampouco tódolos xuíces podían dispoñer dalgún exemplar, sobre todo nos pequenos tribunais; neste caso, a pervivencia do Liber limitábase ás nocións que o xuíz tiña para poder levar adiante o proceso «sicut lex gotica ordinaverat», seguindo unhas «maneiras de facer» góticas que tódolos litixios van seguir. Pero cando se recurría ó Libro a decisión quedaba sacralizada coa forza da tradición visigoda, coa forza da Lex, ata o punto de que moitas veces o interés (do xuíz ou, máis ben, da parte beneficiada) en que a referencia á lei gótica quedase rexistrada contentábase cunhas poucas palabras, ás veces tan manipuladas que nin sentido tiñan, inintelixibles para moitos, pero que os puña frente ó inconmensurable poder da lei. Citas explícitas ou meras fórmulas, uso xurídico- práctico ou uso cultural, uso "diplomático" ou uso procesual, coñecemento real ou simple fascinación, a Lex e o Liber mantiveron no reino de León unha idea total de legalidade no período que vai dende a invasión árabe ata o progresivo consolidamento dos fueros que, si se concebiron como algo, foi como modificación e axeitamento da Lex ás novas circunstancias sociais dos séculos XI e XII, pero non como a súa sustitución.

"CUADERNOS DE ESTUDIOS GALLEGOS", Tomo XLIV, Fascículo 109, Santiago 1997. 
Táboa I: Denominacións empregadas para referirse á Lex nos documentos do Reino de León

\begin{tabular}{|c|c|}
\hline Denominación & $\begin{array}{c}\mathrm{N}^{\mathrm{o}} \text { de aparicións } \\
\text { (primeira data / última data) }\end{array}$ \\
\hline lex & $142(875 / 1176)$ \\
\hline lex sancta & $3(924 / 1012)$ \\
\hline lex logica (¿por gótica?) & $1(924)$ \\
\hline lex gotica & $52(915 / 1083)$ \\
\hline lex gotorum & $39(931 / 1147)$ \\
\hline gotorum auctoritas & $1 \quad(972)$ \\
\hline lex iudicum & $1(1072)$ \\
\hline $\begin{array}{l}\text { lex quod gloriosis principes } \\
\text { nostri constituerunt... }\end{array}$ & $6(967 / 1055)$ \\
\hline damna legum & $9(911 / 1024)$ \\
\hline $\begin{array}{l}\text { auctoritas legum, } \\
\text { legum ordinem, } \\
\text { sententia legis, volumine legis }\end{array}$ & $14(886 / 1102)$ \\
\hline leges pacificas, leges publicas & $4(909 / 1022)$ \\
\hline $\begin{array}{l}\text { in liber iudicum, in libro iudicatum, } \\
\text { in libro iudiciale }\end{array}$ & $65(889 / 1154)$ \\
\hline in liber godorum & $6(1007 / 1113)$ \\
\hline in liber gotice, librum goticum & $3(938 / 1072)$ \\
\hline $\begin{array}{l}\text { in liber V... (especificación } \\
\text { do libro, título e sentencia) }\end{array}$ & $37(875 / 1110)$ \\
\hline scripture, lex et scriptura & $3(1040 / 1068)$ \\
\hline $\begin{array}{l}\text { sapetores et doctores legis, } \\
\text { latores legum, speculatorem legem }\end{array}$ & $4(1021 / 1076)$ \\
\hline
\end{tabular}

"CUADERNOS DE ESTUDIOS GALLEGOS", Tomo XLIV, Fascículo 109, Santiago 1997. 
Táboa II: Leis do Liber identificadas nos documentos do Reino de León

\begin{tabular}{|c|c|}
\hline \multicolumn{2}{|r|}{ Libro II: De negotiis causarum } \\
\hline II, 1,2 & Celanova 1054 \\
\hline II,1,6 & Celanova 1054 \\
\hline II,1,8 & $\begin{array}{l}\text { Valencia de Don Juan } 875 \text {, Santiago } 886 \text {, León } 992 \text {, } \\
\text { Celanova } 994 \text { e } 995 \text {, Otero de las Dueñas 1012, León } \\
1017 \text {, Otero de las Dueñas } 1019 \text {, León 1023, Lugo } \\
1029 \text {, Otero de las Dueñas } 1032 \text { e Sahagún } 1059\end{array}$ \\
\hline II, 1,23 & Braga 1025 \\
\hline II, 1,30 & Braga 1103 \\
\hline II $, 4,2$ & Sahagún 1063 e Arauca 1091 \\
\hline $\mathrm{II}, 4,3$ & Sahagún 1067 \\
\hline $\mathrm{II}, 4,5$ & Braga 1025 \\
\hline$\Pi, 4,6$ & Oviedo 1050 \\
\hline II,5,? & Santiago 919, León 932 e 1022 \\
\hline II,5,12 & $\begin{array}{l}\text { León 1025-1035, Celanova 1032, Coimbra 1040, León } \\
1049 \text { e Oviedo } 1075\end{array}$ \\
\hline \multicolumn{2}{|r|}{ Libro III: De ordine coniugali } \\
\hline III, $1, ?$ & León 1079 \\
\hline III,3,1 & Otero de las Dueñas 1022 \\
\hline III $, 4,3$ & León 994 \\
\hline III $, 5,4$ & Santiago de León 1006 \\
\hline III,6,? & Sahagún 1059 \\
\hline III,6,2 & Moreira 1046 \\
\hline \multicolumn{2}{|r|}{ Libro IV: De origine naturali } \\
\hline $\mathrm{IV}, 2,12$ & Oviedo 1083 \\
\hline IV $, 2,18$ & $\begin{array}{l}\text { Guimarães 959, Sobrado 960, León 1038, Oviedo } \\
1058 \text { e León } 1066\end{array}$ \\
\hline $\mathrm{IV}, 2,20$ & $\begin{array}{l}\text { León } 952 \text {, Celanova } 972 \text {, Samos } 978 \text { e } 989 \text {, Coimbra } \\
1013,1014,1032,1041,1043 \text { e } 1045 \text {, Braga } 1058 \\
\text { Pedroso } 1060 \text { e } 1068, \text { Braga } 1072,1077 \text { e } 1088 \text {, }\end{array}$ \\
\hline
\end{tabular}

"CUADERNOS DE ESTUDIOS GALLEGOS", Tomo XLIV, Fascículo 109, Santiago 1997. 


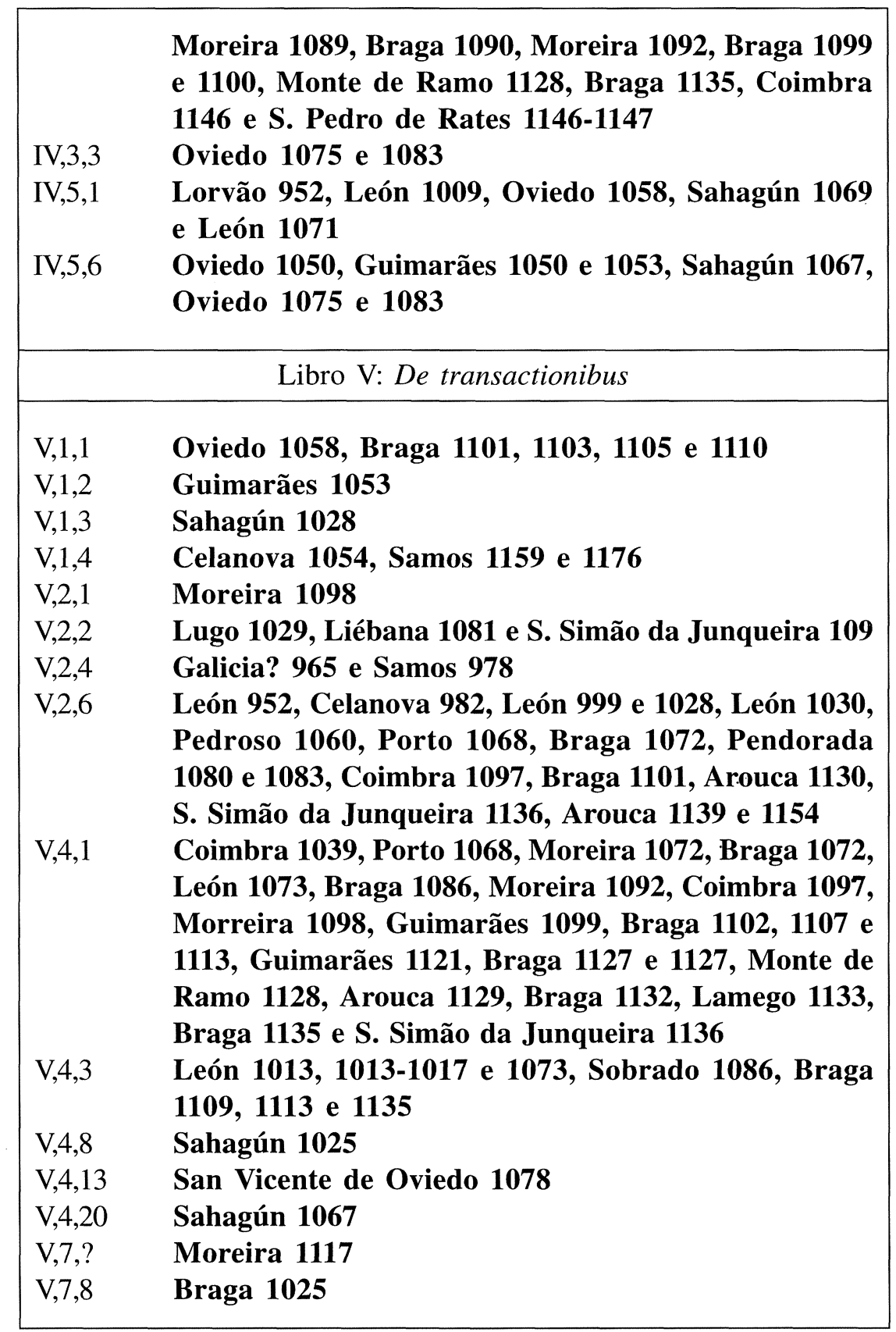

"CUADERNOS DE ESTUdIOS GALLEGOS", Tomo XLIV, Fascículo 109, Santiago 1997. 
Libro VI: De sceleribus et tormentis

\begin{tabular}{|ll|}
\hline \multicolumn{2}{|c|}{ Libro VI: De sceleribus et tormentis } \\
\hline VI,5,12 & León $\mathbf{1 0 2 0}$ \\
\hline & Libro VIII: De inlatis violentiis et damnis \\
\hline VIII,1,6 & Otero de las Dueñas $\mathbf{1 0 1 8}$ e $\mathbf{1 0 1 9}$ \\
\hline \multicolumn{2}{|c|}{ Libro IX: De fugitivis et refugientibus } \\
\hline IX,3,1 $\quad$ Oviedo $\mathbf{1 0 5 0}$ \\
\hline Libro X: De divisionibus et annorum temporibus adque limitibus \\
\hline X,2,3 & Oviedo $\mathbf{1 0 7 5}$ e $\mathbf{1 0 8 3}$ \\
\hline
\end{tabular}

Para facilitar a localización dos documentos mencionados, faise a continuación unha relación das fontes editadas manexadas que nos forneceron de información para este traballo:

BARRAU-DIHIGO, Lucién, «Chartes royales lèonaises 912-1037», en Revue Historique 10 (1903), pp. 350-454. ${ }^{69}$

COELHO, Maria Helena da Cruz, O mosteiro de Arouca. Do século X ao século XIII, Arouca 1988.

COSTA, Avelino de Jesús da Costa, $O$ bispo Pedro e a organizaçao da diocese de Braga, II, Coimbra 1959.

id., Liber Fidei Sanctae Bracarensis ecclesie, sep. de O Distrito de Braga, 2 vols., Braga 1965-1978.

\footnotetext{
${ }^{69}$ Esta edición, xunto coas que fai SERRANO Y SANZ, foron as que nos permitiron coñecer os documentos de Celanova, xa que este traballo se realizou antes da publicación do Tumbo de Celanova, editado por J. M. ANDRADE CERNADAS; non é de dubidar que a dispoñibilidade do tumbo completo había de enriquecer este achegamento ó uso e coñecemento do Liber.
}

"CUADERNOS DE ESTUDIOS GALLEGOS", Tomo XLIV, Fascículo 109, Santiago 1997. 
Documentos Medievais Portugueses. Documentos régios, I: Documentos dos condes portugalenses e de D. Alfonso Henriques, A.D. 1095-1185, I, Lisboa 1958.

Documentos Medievais Portugueses. Documentos particulares, vol. IV, t. I, A.D. 1116-1123, Lisboa 1980.

FERNÁNDEZ CATÓN, José $\mathrm{M}^{\mathrm{a}}$, «Documentos leoneses en escritura visigótica. Fondo M. Bravo del Archivo Histórico Diocesano de León», en León y su historia II, León 1973, pp. 203-295.

id., «Documentos leoneses en escritura visigótica. Fondo Raimundo Rodríguez del archivo catedral de León», en León y su historia III, León 1975, pp. 469-511.

FERNÁNDEZ CONDE, Francisco J., e outros, El monasterio de S. Pelayo de Oviedo, I, Oviedo 1978.

FERNÁNDEZ DEL POZO, José María, «Alfonso V, rey de León», en León y su historia $V$, León 1984, pp. 165-251.

FLORIANO CUMBREÑO, Antonio C., Diplomática española del período astur I, Oviedo 1949.

FLORIANO LLORENTE, Pedro, Colección diplomática del monasterio de San Vicente de Oviedo, Oviedo 1968.

id., «El fondo antiguo de pergaminos del Instituto Valencia de D. Juan», en B.R.A.H., $3^{\circ}$ caderno (1971), pp. 441-513.

HERRERO, Marta, Colección diplomática del monasterio de Sahagún (857-1230). II (1000-1073), León 1988.

JUSUÉ, Eduardo, «Documentos inéditos del cartulario de $\mathrm{S}^{\text {to }}$ Toribio de Liébana», en B.R.A.H. 48 (1906), pp. 131-139.

LÓPEZ FERREIRO, Antonio, Historia de la S.A.M. Iglesia de Santiago de Compostela, Santiago 1899-1910, tomos I e II.

"CUADERNOS DE ESTUDIOS GALLEGOS", Tomo XLIV, Fascículo 109, Santiago 1997. 
LOSCERTALES, Pilar, Tumbos del monasterio de Sobrado de los Monjes, Madrid 1976.

LUCAS ÁlVAREZ, Manuel, El tumbo de S. Julián de Samos (s. VIIIXII), Santiago 1986.

MÍNGUEZ FERNÁNDEZ, José María, Colección diplomática del monasterio de Sahagún (siglos IX-X), León 1977.

NÚÑEZ CONTRERAS, Luis, «Colección diplomática de Vermudo III, rey de León», en Historia Instituciones Documentos 4, Sevilla 1977, pp. 381-514.

Portugaliae Monumenta Historica. Diplomata et Chartae, I, Lisboa 1867. (reed. anastática Liechtenstein, 1967).

PRIETO MORERA, Agustín, «Documentos referentes al orden judicial del monasterio de Otero de las Dueñas», en A.H.D.E. 44 (1974), pp. 619-674.

id., «Documentos referentes al orden judicial del monasterio de Sahagún», en A.H.D.E. 45 (1975), pp. 489-541.

RODRÍGUEZ GONZÁLEZ, Ángel, El tumbo de S. Martín de Castañeda, León 1973.

RODRÍGUEZ FERNÁNDEZ, Justiniano, El monasterio de Ardón, Madrid 1964.

RUÍZ ASENCIO, José M., Colección documental del archivo de la catedral de León (775-1230). III (986-1031) e IV (1032-1109), León 1987 e 1989.

SÁEZ SÁNCHEZ, Emilio, «Documentos gallegos inéditos del período asturiano», en A.H.D.E. 18 (1947), pp. 399-431.

id., Colección documental del archivo de la catedral de León (775-1230). I (775-952) e II (953-985), León 1987 e 1990.

"CUADERNOS DE ESTUDIOS GALLEGOS", Tomo XLIV, Fascículo 109, Santiago 1997. 
SÁNCHEZ BELDA, Luis, Cartulario de Santo Toribio de Liébana, Madrid 1948.

SÁNCHEZ CANDEIRA, Alfonso, «Entorno a cinco documentos inéditos de Vermudo III», en C.H.E. 11 (1949), pp. 153-165.

SERRANO Y SANZ, Manuel, «Documentos del cartulario del monasterio de Celanova», en Boletín de la Biblioteca Menéndez Pelayo III (1921), pp. 263-278 e 301-320.

id., «Documentos del monasterio de Celanova (años 975-1164)», en Revista de Ciencias Jurídicas y Sociales XII (1929), pp. 5-47 e 512524.

YÁÑEZ CIFUENTES, Ma del Pilar, El monasterio de Santiago en León, León 1972. 